\title{
Cross-sectional anatomy and geodynamic evolution of the Central Pontide orogenic belt (northern Turkey)
}

Hippolyte*, J-C (1) ,Espurt, N. (1), Kaymakci, N. (2), Sangu, E. (3), Müller, C. (4)

(1) Aix-Marseille Université, CNRS, IRD, CEREGE UM34, 13545, Aix-en-Provence, France

(2) Middle East Technical University ODTU-METU, Department of Geological Engineering, 06800, Ankara, Turkey

(3) Kocaeli University, Department of Geological Engineering, 41380, Kocaeli, Turkey

(4) PL-66-431b Santok, Ludzislawice 36, Poland

*Corresponding author:

Jean-Claude HIPPOLYTE

CEREGE

BP 80, Europole Mediterraneen de l'Arbois

13545 Aix en Provence Cedex 4, FRANCE

Tel. +334429717 70

e-mail: hippolyte@cerege.fr

\begin{abstract}
:
Geophysical data allowed the construction of a 250-km-long lithospheric-scale balanced cross section of the southern Black Sea margin (Espurt et al. 2014). In this paper we combine structural field data, stratigraphic data, and fault kinematics analyses with the $70 \mathrm{~km}$-long onshore part of the section to reconstruct the geodynamic evolution of the Central Pontide orogen. These data reveal new aspects of the structural evolution of the Pontides since the Early Cretaceous. The Central Pontides is a doubly vergent orogenic wedge that results from the inversion of normal faults. Extensional subsidence occurred with an ENE-trend from Aptian to Paleocene in a forearc setting. We infer that the Black Sea back-arc basin also opened during this period, which was also the period of subduction of the Tethys Ocean below the Pontides. As in the Western Pontides, the Cretaceous-Paleocene subsidence was interrupted from Latest Albian to Coniacian time by uplift and erosion that was probably related to a block collision and accretion in the subduction zone. The restoration of the section to its preshortening state (Paleocene) shows that fault-related subsidence locally reached $3600 \mathrm{~m}$ within the forearc basin. Structural inversion occurred from Early Eocene to MidMiocene as a result of collision and indentation of the Pontides by the Kırşehir continental block to the south, with $27.5 \mathrm{~km}$ ( 28\%) shortening along the section studied. The inversion was characterized by NNE-trending shortening that predated the Late Neogene dextral escape of Anatolia along the North Anatolian Fault and the modern stress field characterized by NW-trending compression within the Eocene Boyabat basin.
\end{abstract}

Keywords: Pontides; Black Sea; North Anatolian fault; cross section; paleostress; geodynamics 


\section{I- Introduction}

The Pontide mountain belt extends for more than $1100 \mathrm{~km}$ in an east-west direction along the Black Sea coast (Fig. 1). This belt corresponds to a segment of the Alpine-Himalayan belt between the Rhodopes in the west and the Caucasus in the east.

The Pontides rifted away from the South Eurasian margin during the opening of the Black Sea Basin that probably started during Late Barremian or Aptian time (e.g. Finetti et al. 1988; Görür 1988; Robinson et al. 1996; Hippolyte at al. 2010; Nikishin et al. 2015), and was shaped by the collision of microcontinents including the Kırşehir and the Anatolide-Tauride blocks following the Cretaceous subduction of Neotethys (Fig. 1; e.g. Şengör and Yılmaz 1981; Okay et al. 1994; Lefebvre et al. 2013).

Despite intense mapping and petroleum exploration the geodynamic and structural evolution of the Pontide belt is still poorly constrained. The Sinop-Boyabat area is the best documented region of the Pontides as a result of hydrocarbon exploration, because the Lower Cretaceous syn-rift sequence of the Boyabat basin was a drilling objective (Sonel et al. 1989; Aydın et al. 1995; Görür and Tüysüz 1997; Şen 2013). Using onshore and offshore data we constructed a lithospheric scale cross section from the Central Pontides (Boyabat) to the middle of the Black Sea (Espurt et al. 2014). This is the first balanced and restored cross section of the southern Black Sea margin. This section shows that the structure of the onshore Pontides is predominantly controlled by inverted normal faults and contrasts with the offshore areas devoid of large structural inversion.

This paper is aimed at determining the structural and geodynamic evolution of the Central Pontides (Fig. 1) by combining stratigraphic data with fault kinematic analyses and structural observations. In particular we present in detail the main structural data that constrain the architecture of the onshore part (70 km long) of the lithosphere-scale $250-\mathrm{km}$-long cross section that was previously published (Espurt et al. 2014). This work benefits from major new exposures along a road constructed between Sinop and Boyabat, some of which were studied by Şen (2013), and also from observations along the pre-existing road. These two roads have allowed us to work on more than 180 outcrops at two different elevations on the same cross section: both near mountain tops, and near the valley floor. We combine structural observations with fault kinematic studies (228 fault planes) and palaeostress reconstructions (23 paleostress diagrams) to constrain the geodynamics of this belt. To constrain the timing of the structural evolution we have dated 32 samples using nannoplankton fauna. These age determinations allow us to propose a new stratigraphic log for the Central Pontides (Fig. 2). This multidisciplinary approach provides new insights on the multistage geodynamic evolution of the Central Pontides from Early Cretaceous to Present times.

\section{II- Geological setting}

\section{1) Plate tectonic setting}

The Pontides orogenic belt consists of a mountain chain in northern Anatolia (Turkey) that delineates the southern Black Sea coast (Fig. 1). Much of the crust of Anatolia formed by accretion of Gondwana-derived micro-continents to the southern margin of Eurasia during the closure of the Paleotethyan and the Neotethyan oceans from Jurassic to Eocene time (e.g. Şengör and Yılmaz 1981; Okay and Tüysüz 1999; Okay et al. 2006; Ustaömer and Robertson 1997; Pourteau et al. 2010). Behind the north- 
dipping Neotethyan subduction zone, the Black Sea opened as a back-arc basin from Cretaceous to Paleocene time (Hsu et al. 1977; Letouzey et al. 1977; Şengör and Yılmaz 1981; Zonenshain and Le Pichon 1986; Görür 1988; Okay et al. 1994; Robinson et al. 1996; Stephenson and Schellart 2010; Graham et al., 2013; Nikishin et al. 2015). Before the Black Sea opened, the Pontides represented the southern Eurasian margin (e.g. Şengör and Yılmaz 1981).

The Pontide mountain belt resulted from the collision of the Kırşehir continental block (Central Anatolian Crystalline Complex, e.g. Kaymakci 2000; Lefebvre et al. 2013) and the Anatolide-Tauride continental block, with the İstanbul and Sakarya Zones (Fig. 1). These blocks are now separated from the Pontides by an ophiolitic belt, the AnkaraErzincan suture zone that resulted from the northward subduction of the Neotethyan ocean (Şengör and Yılmaz 1981; Okay 1989; Kaymakci et al. 2003b; 2009; Rice et al. 2009; Meijers et al. 2010; Lefebvre et al. 2013; Okay et al. 2013) (Fig. 1). The Kırşehir block and the Anatolide-Tauride continental block represent two distinct continental masses that were also separated by Neotethyan oceanic crust, the closure of which generated high-grade metamorphism during late Cretaceous to early Cenozoic time (Pourteau et al. 2010).

The age of the Pontides is not well constrained between Late Cretaceous and Recent. Shortening and tectonic uplift mainly occurred during the Eocene and are still locally active (Belousov et al. 1988; Robinson et al. 1996; Reilinger et al. 2006; Yıldırım et al. 2011; Espurt et al. 2014). However, the evidence from the stratigraphic sequences suggests that the Kırşehir block started to dock as early as the Late Cretaceous or Paleocene time. Paleomagnetic data show that block rotations, interpreted to have resulted from oroclinal bending, occurred during the Paleocene (eg. Kaymakci et al. 2003 a and b; Meijers et al. 2010). During Late Cenozoic times, part of the AnkaraErzincan suture zone was reactivated with a strike-slip motion by the North Anatolian Fault (e.g. Şengör et al. 1985; Facenna et al. 2006).

\section{2) Crustal structure of the Pontides}

The Pontide mountain belt is classically divided into the Western Pontides with Istanbul Zone basement, and the Central and Eastern Pontides with Sakarya Zone basement, both covered by unmetamorphosed Jurassic to Eocene sedimentary rocks (e.g. Şengör and Y1lmaz 1981; Y1lmaz et al. 1997; Fig. 1). The Istanbul Zone is characterized by an unmetamorphosed Paleozoic (Ordovician to Carboniferous) sedimentary sequence which unconformably overlies pre-Cambrian metamorphic rocks. In contrast, the Sakarya Zone contains no Paleozoic sedimentary rocks and underwent strong deformation and metamorphism during the Late Triassic (e.g. Şengör and Yılmaz 1981; Okay 1989).

The limit between these two terranes, named the Intra-Pontide Suture was interpreted as the suture of the northern branch of Neo-Tethys (Şengör and Yılmaz 1981) or as a "narrow Gulf of California type ocean" (Okay 1989). However, its origin is still under debate and we refer to Okay (1989), Yılmaz et al. (1997), Stampfli et al. (2001), Roberston and Ustaömer (2004), Yiğitbaş et al. (2004), Elmas and Yiğitbaş (2005), Akbayrama (2013), for further details. Immediately east of the Intra-Pontide Suture, the Kure complex, a thick sequence of deep sea sedimentary rocks intercalated with dismembered ophiolite, was interpreted as a Late Paleozoic-Early Triassic marginal basin (Ustaömer and Robertson 1997). In the Kargı Massif, south of Boyabat (Fig. 1), rocks 
classically interpreted as Middle Triassic to Lower Jurassic schists, metabasites and serpentinites (e.g. Şengör et al. 1984; Okay 1989; Uğuz et al. 2002) provided metamorphic ages indicating subduction and collision of an oceanic plateau (Domuzdağ complex) during the Early Cretaceous (Okay et al. 2006; 2013). Our study area is located in the Central Pontides north of the Kargı Massif, and in the Sakarya Zone (Fig. 1). In this paper, we will describe the Cretaceous-Neogene structures, which are less well known.

\section{3) Sedimentary cover of the Pontides}

If we consider the sedimentary cover, the Western (Istanbul Zone) and Central (Sakarya Zone) Pontides (Fig. 1) are characterized by similar Mesozoic-Tertiary stratigraphic sequences and large Early Cretaceous sedimentary basins (e.g. Hippolyte et al. 2010). The Central Pontides contrast with the Eastern Pontides, which also belong to the Sakarya Zone but are characterized by thick volcanic and volcano-sedimentary rocks cut by steeply dipping faults (e.g. Okay and Şahintürk 1997; Ustaömer and Robertson 2010; Eyuboglu et al. 2013). During the Late Jurassic a large carbonate platform covered much of the Pontide terranes. In the post-Upper Jurassic stratigraphic sequence of the Western and Central Pontides we can distinguish three main periods of basin subsidence: Early Cretaceous, Late Cretaceous-Paleocene and Eocene-Miocene.

During the Early Cretaceous, there were both deep and shallow basins in the Western and Central Pontides (Fig. 1). The deep flysch basins are, the Ulus basin of Hauterivian to Late Aptian age (Hippolyte et al. 2010), and the Cretaceous Boyabat basin that is probably its eastern prolongation (Görür and Tüysüz 1997), and which will be discussed here (Fig. 1). These flysch basins probably formed near a subduction zone (Hippolyte et al. 2010; Okay et al. 2013). The shallow-marine basins are the Zonguldak and Amasra basins that are located along the Black Sea coast. They were dominantly filled by clastic sediments from Late Barremian to Latest Albian time (Hippolyte et al. 2010). Their location along the Black Sea margin, their stratigraphic evolution, and the presence of numerous normal faults along the black sea coast suggest that they are related to the rifting of the Western Black Sea Basin (Ketin and Gümüş 1963; Görür et al. 1993; Görür 1997; Hippolyte et al. 2010).

A second period of subsidence, during the Late Cretaceous-Paleocene, corresponds to the formation of the Bartın basin and the Sinop-Boyabat basin (now the Sinop Range; e.g. Leren 2003), extending from Cide to Samsun between the Early Cretaceous basins (Fig. 1).

Unconformably overlying the Cretaceous basins and older rocks, there are Cenozoic basins that are mainly filled with Eocene marine sediments: Devrek, Eflani, Karabük, Kastamonu, Devrekani and Boyabat basins (Fig. 1). Considering their structural setting and their terrigenous infill they are interpreted as syn-compressional basins (e.g. Hippolyte et al. 2010).

Therefore, the study area in the Central Pontides includes Early Cretaceous, Late Cretaceous-Paleogene, and Eocene basins typical of the Western and Central Pontides, and a Sakarya Zone basement typical of the Central and Eastern Pontides. Moreover, the Sinop peninsula provides onshore access to a large portion of the belt and its structures. This area underwent little or no block rotation according to paleomagnetic studies (Channell et al. 1996; Meijers et al. 2010; Fig. 1) and therefore reconstructed paleostress orientations do not need correction. 


\section{III- Stratigraphic sequence and new nannoplankton ages}

The sedimentary cover of the Central and Western Pontides starts with the Bürnük Formation (Ketin and Gümüş 1963). This comprises red continental conglomerates of probable Middle-Late Jurassic age, a few tens of meters thick. This formation is overlain by the Upper Jurassic-Lower Cretaceous platform carbonates of the İnaltı Formation (Ketin and Gümüş 1963; Derman and Sayili 1995) (Fig. 2).

During the Early Cretaceous, the sedimentation changed throughout the Central and Western Pontides from shelf carbonates to detrital deposits of the Çağlayan Group (Kilimli, Sapça and Tasmaca Formations). These formations, which were mainly studied in the Zonguldak basin (Fig. 1), were considered to be of Aptian to Cenomanian age (e.g. Görür 1997; Tüysüz, 1999). Nannoplankton assemblages have revealed that the Sapça and Tasmaca Formations are of only Aptian to Early Albian age, and that in much of the Western Pontides there is a stratigraphic gap from the uppermost Albian to the Turonian (Hippolyte et. al. 2010) (Fig. 2).

Along our cross section, in the Boyabat basin, the Çağlayan Group is represented by a unique formation of siliciclastic turbidites named the Çağlayan Formation (Ketin and Gümüş 1963). This consists of black shales, turbiditic sandstones, limestone debrisflow intercalations and olistoliths, deposited in a deep basin (Fig. 2). The well, Boyabat-3 cuts into 3400 meters of this formation (Aydın et al. 1995; Şen 2013; Fig. 3). In the Cretaceous Boyabat basin, we found nannoplankton assemblages of only Aptian age (Fig. 2). The Albian seems to be missing as in the Ulus basin, its western prolongation (Hippolyte et al. 2010) (Fig. 2).

The turbidites of the Çağlayan Formation are unconformably overlain by the Kapanboğazı Formation (Ketin and Gümüş 1963; Görür et al. 1993; Tüysüz 1999; Tüysüz et al. 2012). This is a well-bedded red (hematite rich) pelagic micritic limestone which belongs to the typical Cretaceous oceanic red beds (CORBs) of the Tethys ocean (Hu et al. 2005). The thickness is generally about 20-30 meters. In the Western Pontides the basal unconformity was interpreted as a post-breakup unconformity, whereas the drastic change in sedimentation from clastic to carbonates was interpreted as representing the onset of sea floor spreading in the Black Sea Basin during the Late Cenomanian (Görür et al. 1993; Görür and Tüysüz 1997). Also in the Western Pontides we have shown that this unconformity is locally a large angular unconformity that resulted from Middle Cretaceous erosion (Hippolyte et al. 2010). Nannoplankton assemblages have constrained the age of the Kapanboğazı Formation as ConiacianSantonian confirming that the erosional unconformity corresponds to a large stratigraphic gap (Hippolyte et al. 2010).

This younger age of the Kapanboğazı Formation is confirmed in the Central Pontides by stratigraphic sections immediately west of our study area that have nannoplankton assemblages of Santonian age, possibly extending down to Coniacian (Okay et al. 2006), and also by nannoplankton assemblages of Santonian-Lower Campanian age in sample 96C (Fig. 2 and 3, Table 1). These ages and the observation of an angular unconformity $6 \mathrm{~km}$ north of Hanönü (Fig. 3) indicate that the Mid-Cretaceous stratigraphic gap found in the Western Pontides also exists in the Central Pontides where it may encompass Albian-Coniacian time (Fig. 2).

The Kapanboğazı red pelagic limestone is overlain by a thick formation of basaltic-andesitic volcaniclastic and volcanic rocks named the Yemişliçay Formation (Ketin and Gümüş 1963). Its thickness increases from $20 \mathrm{~m}$ near Boyabat, to $2200 \mathrm{~m}$ in 
the middle of the Sinop Range, where it crops out extensively. In agreement with previous studies (e.g. Görür et al. 1993) our nannoplankton age data indicate that the upper part of this thick succession reaches the Early Campanian in the Sinop area (Fig. 2) whereas in the Western Pontides the age is restricted to Coniacian-Santonian (Hippolyte et al. 2010).

In the Central Pontides, this unit is overlain by non-volcanogenic siliciclastic turbidites of the Gürsökü Formation, of Campanian Maastrichtian age (Tüysüz 1999; Leren et al. 2007). Our samples yielded Lower Campanian to Lower Maastrichtian nannoplankton assemblages (Fig. 2). Similar to the Yemişliçay Formation, the thickness of this formation varies greatly from $200 \mathrm{~m}$ near Boyabat to $2000 \mathrm{~m}$ in the Sinop Range (Fig. 3).

The Gürsökü Formation grades upwards into calciturbidites of the Akveren Formation marking the development of a carbonate slope-apron system that evolved to a carbonate ramp and a reefal platform (Ketin and Gümüş 1963; Leren 2003). West of Boyabat, near Hanönü (Fig. 3), this formation is represented by massive white limestone unconformably overlying older formations, whereas in the Sinop Range it is represented by thick white calciturbidites alternating with grey clays. Nannoplankton fauna indicate a Late Maastrichtian to Late Paleocene age for this formation, which is up to $1.2 \mathrm{~km}$ thick.

The Akveren carbonaceous sequence is conformably overlain by the typical variegate mudstones (black to reddish) of the Atbaşı Formation (Aydın et al. 1995). These mudstones indicate a rapid rise in sea level, reduced sedimentation rate and extensive seafloor oxidation, which were interpreted as marking a pulse of rifting (Leren 2003). Its traditional Paleocene-Early Eocene age (Aydın et al. 1986) is in agreement with the Upper Paleocene (NP9 zone) nannoplankton fauna of site SI-24 (Fig. 2 and 3).

In the Sinop basin the Atbaşı Formation is overlain by the Lower-Middle Eocene Kusuri Formation (Aydın et al. 1986; Görür and Tüysüz 1997), consisting of turbiditic sandstones and mudstones that yielded an Early Eocene age (NP12 zone) at site SI-11 (Fig. 2 and 3). According to the seismic lines used for our cross-section, this formation may be about $2000 \mathrm{~m}$ thick in the Sinop Basin, and up to $3000 \mathrm{~m}$ thick in the Eocene Boyabat basin ( $2.8 \mathrm{~km}$ in well Boyabat-2) where it might be thickened by constractional deformation. The Kusuri Formation represents a major change in sedimentation with the activation of siliciclastic sources and large channelized turbidity currents (Leren 2003).

In the Sinop Basin the Eocene succession is overlain with stratigraphic onlap by the Middle Miocene-shallow-marine calcarenites, yellowish cross-bedded sandstones and fluvial deposits of the Sinop and Gelincik Formations. According to seismic lines, these formations may be up to $1600 \mathrm{~m}$ thick. It is notable that the Oligocene-Lower Miocene Maikop clayey sequence of the Eastern Paratethys (e.g. Stolyarov and Ivleva 2006), which is an important source rock in the Black Sea area, is not present in outcrop along the section, but we cannot exclude its presence at depth in the Sinop Basin.

Within the Eocene Boyabat basin, the Kusuri turbiditic sandstone passes laterally (to the south) to blue clays and to a Middle Eocene reefal nummulitic limestone (Boyabat Limestone Formation; Ketin and Gümüş 1963; Şen 2013). These marine deposits are overlain by a several hundred meter-thick continental conglomerate of unknown age, named the Cemalettin Formation (Aydın et al. 1995). Nannoplankton fauna indicate an Early to Middle Eocene age for the marine part of the Boyabat basin 
sequence (nannoplankton zones 12 to 14, Fig. 2), which suggests a Late EoceneOligocene age for the overlying Cemalettin Formation.

\section{IV- Compressional deformation and shortening direction}

Mountain belts may result from one or several shortening episodes. The knowledge of the shortening directions and their timing is fundamental for cross section analysis. If the section trace is parallel to the shortening direction (perpendicular to the structures) one can correctly estimate shortening and restore the structures before contraction. To estimate the shortening direction we measured 162 bedding planes along the two roads between Boyabat and Sinop. We used the Stereonet 8 software by Rick Allmendinger to analyze statistically the bedding plane attitudes. The cylindrical best fit analysis (Allmendinger et al. 2012) of the 162 bedding planes measurements gave a great circle oriented N18E, which is nearly parallel with the Sinop-Boyabat transect (Fig. 3a).

However, we note in Figure $3 a$ that the distribution of bedding plane attitude is not homogeneous and the dip direction varies up to $113^{\circ}$ for large dips value (between N137E and N250E). To determine if the finite deformation resulted from non-co-axial shortening episodes, we carried out paleostress analysis throughout the study area (Fig. 3). While computing paleostresses from fault slip data, one can determine if the fault population corresponds to a single state of stress or to successive non co-axial states of stress, according to the value of the quality estimator ANG (angle between the computed resolved shear stress and the measured striation, Angelier 1990). We can furthermore separate the successive states of stress and the fault populations.

We measured striated fault planes at seventeen fault sites (Table 2). Eleven sites showed compressional to strike-slip state of stress, with a common maximum principal stress axis trending NNE-SSW, in good agreement with the analysis of the bedding planes dips (Fig. 3). However, three sites revealed another (NW-SE) trend of compression (sites Boya-19, Boya-7, Boya-5; fig. 4). This contrasting trend cannot have resulted from block rotations because paleomagnetic data do not indicate any significant block rotations within the Central Pontides (Channell et al. 1996; Meijers et al. 2010). We conclude that the compressional deformation is locally polyphase.

Two sites with polyphase deformation indicate that the NW-SE compression postdated the main NE-SW to NNE-SSW event (Fig. 4). At site Boya-19, the conjugate reverse faults that formed during a NE-SW compression were later tilted with the bedding planes by the more recent NW-SE compression (Fig. 4). At site Boya-5, the chronology of striation on a NNE-trending fault plane also indicates that the NWtrending compression postdated the NE-trending compression (Fig. 4).

The fact that the two tectonic events affect the youngest formation of the Eocene Boyabat basin, the Cemalettin Formation (Fig. 3), suggests that the first event was contemporaneous with the infill of the syn-compressional Boyabat basin during the Eocene uplift of the Sinop Range, and that the second event postdated the Eocene. In contrast with the main NNE-SSW compression, the NW-SE trend of the recent compression is compatible with the dextral slip of the North Anatolian Fault and the Quaternary stress field (NW-SE compression; Andrieux et al. 1995). We infer that the NW-SE compression corresponds to a local tectonic reactivation of the Pontides, in agreement with recent geomorphological analyses (Yıldırım et al. 2011). However, we point out that in the study area, faults related to this recent reactivation are mainly 
found in the Eocene Boyabat basin. Most of the structures in the Sinop Range trend ESEWNW and have resulted from NE-SW to NNE-SSW compression.

Our cross sections between Boyabat and Sinop is oriented N24E (Fig. 3; Espurt et al. 2014). It is therefore parallel to the main compressional structures and can be accurately equilibrated and restored. The two roads between Boyabat and Sinop are ideally oriented to study the structures along the cross section.

\section{V- Cross-sectional anatomy and outcrop scale structures of the Boyabat-Sinop area}

\section{1) Previous studies}

Only a few schematic cross sections of the Boyabat-Sinop transect have been previously published (Aydın et al. 1995; Görür and Tüysüz 1997; Robinson and Kerusov 1997; Yıldırım et al. 2011). These sections generally predate the new road construction and its associated large outcrops. Aydın et al. (1995) modelled the Pontides as a doubly vergent structure resulting from the inversion of Upper Jurassic-Lower Cretaceous horsts and grabens. Görür and Tüysüz (1997) modelled a series of symmetrical folds and thrusts that developed above a south-dipping main décollement lying within the Lower Cretaceous flysch of the Çağlayan Formation. To explain thickness changes across the Ekinveren fault (Aydın et al. 1995; Görür and Tüysüz 1997), Robinson and Kerusov (1997) proposed that the Sinop Range is an inverted Mid-Cretaceous half graben. Şen (2013) emphasized that a central (Çangaldağ) anticlinorium is bordered to the north and to the south by fold-thrust zones with duplex structures. Yıldırım et al. (2011) drew a doubly vergent structure related to the North Anatolian Fault. All models agree that the Sinop Range is a $40-\mathrm{km}$-wide doubly vergent thrust system bounded to the south by the Ekinveren thrust and to the north by the Balıfaki thrust system (Aydın et al. 1995; Fig. 3).

\section{2) Balanced and restored cross section}

\section{a) Method}

In the following we combine the study of outcrop-scale structures with the description of the onshore part of our $\sim 250-\mathrm{km}$-long cross section of the Black-sea margin (Espurt et al. 2014). This 70km-long onshore section was mainly constrained by seven wells and five seismic reflection profiles provided by Turkish Petroleum Affairs database and labeled from 1 to 5 in Figures 3 and 5. A time-depth conversion of each seismic profile was performed using the $V_{0} k$ method. The field data include the study of 180 outcrops along the two roads between Boyabat and Sinop. The reference numbers of the outcrops described in this paper are shown in Figure 3 and on the interpreted synthetic seismic reflection transect (Fig. 5). Balancing and restoration of the cross section were performed with the Move2013 structural modeling software (Midland Valley, Inc.). We restored the cross section for the Paleocene configuration ( 66-56 Ma) before Eocene contraction and inversion (Fig. 6b; see also Espurt et al. 2014).

From south to north, this $70-\mathrm{km}$ long onshore section crosses the metamorphic basement recently named the Central Pontide Supercomplex (Okay et al. 2013) which is covered by the Eocene Boyabat basin, the Sinop Range with Lower and Upper Cretaceous formations, and the Eocene-Miocene Sinop basin (Fig. 3). To clearly display our interpreted seismic lines and to show the location of the main outcrops, we have divided our section into three parts, broadly corresponding to these three structural domains (Fig $5 \mathrm{a}, \mathrm{b}$ and $\mathrm{c}$ ). 


\section{b) Southern part: the Cretaceous Boyabat basin}

The southern part of the section crosses the Boyabat Eocene basin and the Boyabat Cretaceous basin (Fig. 5a). These units are deformed by steep thick-skinned south-verging thrusts involving metamorphic sequences exposed to the north of Boyabat immediately west of the section (site 180, Fig. 3) and its Middle Jurassic to Lower Cretaceous sedimentary cover (Aydin et al. 1995; Şen 2013).

The Ekinveren thrust is a major inverted Cretaceous normal fault (Aydın et al. 1995; Görür and Tüysüz 1997). To the northeast of this thrust, the Boyabat-3 well was drilled into 3400 meters of Çağlayan Formation (e.g. Şen 2013) and the Ekinveren-1 well into $3160 \mathrm{~m}$ without reaching the Jurassic limestone. The top of the Çağlayan sequence is offset along the Ekinveren thrust by more than 2500 meters (Fig. 6a). This fault, and another north-dipping thrust that crosses the Eocene basin to the south (Boyabat Fault, Fig. 5a), are inverted normal faults that bordered the Cretaceous Boyabat basin to the south (Fig. 6b). The restored cross section suggests that the normal downthrows were at least 2000 meters on the Ekinveren fault, and 1800 meters on the Boyabat fault (Fig. 6b).

Two other inverted north-east dipping normal faults are present in the hanging wall of the Ekinveren fault (Fig. 5a). The apatite fission tracks of our sample BO8 (Fig. 3, 6) indicate reheating below the partial annealing zone $\left(80-110^{\circ} \mathrm{C}\right)$, whereas the apatite crystals of sample SI95 and SI72 were only partially reset (Fig. 3, 6, Espurt et al. 2014). This reheating resulted from the burial under a thick Cretaceous-Paleocene sequence. Subsurface data show strong thickness variations (from 3000 $\mathrm{m}$ to less than $300 \mathrm{~m}$ ) in the Lower Cretaceous turbidite sequences across the faults suggesting that these structures are responsible for the tectonic subsidence of the Cretaceous Boyabat basin.

The Early Cretaceous strong subsidence is also indicated by the evolution from a carbonates platform during the Jurassic, to a flysch basin during the Aptian. Field data confirm that this subsidence relates to normal faulting. At site 131, we found conjugate normal faults that have been tilted by subsequent compressional deformation (Fig. 3 and 7). The trend of extension was ENE-WSW (Fig. 7). The chronology of deformation deduced from the compressional tilt of the normal faults is the same as that modeled on the cross section: extension followed by compression. The intercalation of olistoliths and debris flow in the Aptian marly sequence (Fig. 7) supports the interpretation that the normal faults moved during deposition of the Lower Cretaceous sediments.

A fault contact between the Aptian flysch and the Jurassic limestone can be observed at site 113 (Fig. 3 and 8). A large fresh outcrop behind a landslide allows the observation of a fault plane with well-developed oblique striation (Fig. 8e). The limestone and the flysch sequences are folded, and the bedding planes dip $60^{\circ}$ to the north at this location (Fig 8d). To determine what the attitude of the fault was when the bedding planes were horizontal, we rotated the diagram (Fig. 8a). This restoration shows that the oblique fault slip between the Aptian flysch and the Jurassic limestone was originally a dip-slip normal fault. Additional faults measured in the Aptian flysch show that this fault slip, which could have been misinterpreted as compressional deformation (Fig. 9a), resulted from ENE-trending extension (Fig. 9b). Note that the back-tilted trend of extension is the same that at sites 131 (Fig. 7). Moreover, at site 113, intercalations in the Aptian flysch of debris flow deposits with clasts of Jurassic limestone at the toe of the fault plane (Fig. 8d), suggest that the footwall Jurassic limestone was above sea-level and under erosion during Aptian sedimentation. Borings in limestone cobbles found in 
the debris flow intercalations support a model of sea-shore erosion of a limestone fault scarp during Aptian block faulting (Fig. 9b).

Note that in the northern part of this outcrop, the tilted normal fault is cut by a reverse-dextral fault that locally brings the limestone over the Aptian flysch (Fig. 8b and $8 \mathrm{c}$ ). This reverse-oblique fault slip which postdates the extensional deformation is consistent with the general NNE-SSW compressional deformation of the area (Fig. 8b and 4).

\section{c) Southern part: the Eocene Boyabat basin}

Along the Ekinveren thrust, the Cretaceous rocks are thrust over the Eocene Boyabat basin (Fig. 6). This basin is an asymmetric syncline characterized by a steep and sheared northern limb overthrust by the Sinop Range, and by stratigraphic onlap on the metamorphic basement on the south (Fig. 5a and 6). Conglomerates of the Cemalletin Formation are well developed in the southern part of the Boyabat basin (Fig. 3). In contrast, vertical beds of the Eocene Kusuri Formation are exposed along the Ekinveren thrust (Fig. 3). These beds are cut by the North Boyabat fault, which branches to the north on the Ekinveren thrust (Fig. 5a), and terminates to the south on NW-trending kink folds consistent with the NNE-SSW shortening (site 151, Fig 3 and 10).

The Cretaceous Çağlayan flysch was deposited during a time of normal faulting and contains debris flow intercalations and olistoliths. In contrast, the Eocene sequence does not contain debris flow intercalations (Fig. 10). This difference supports the interpretation that the tectonic regime had changed to compressional during the Eocene as concluded from the paleostress analysis. The Eocene basin was filled during NNE-trending compression (Fig. 3). The asymmetric structure of the Eocene Boyabat basin, and its thick sedimentary infill that thins away from the mountain belt, are typical of a pro-arc flexural foreland basin. We interpret this syn-compressional basin as a foreland basin formed during the thrusting of the Sinop Range.

\section{d) Middle part: the Sinop Range}

The Sinop Range is characterized by a high elevation basement covered by a sedimentary sequence that thickens to the north (Fig. 5b). The Lower Cretaceous Çağlayan Formation is only $250 \mathrm{~m}$ thick in the Soguksu-1 well, whereas the Yemişliçay Formation is $1935 \mathrm{~m}$ thick (Fig. 5b). At the northern entrance of the Boyabat (Dranaz) tunnel (site 96, Fig. 3) a trench exposes the Cretaceous sequence (Fig. 11). The black shale of the Çağlayan Formation (Fig. 11b), which crop out over a few tens of meters, is unconformably overlain by the Kapanboğazı red pelagic limestone. Nannoplankton ages of samples SI-96A and SI-96C show that there is a stratigraphic hiatus corresponding at least to the Cenomanian-Coniacian (Fig. 2). This hiatus is equivalent to the MidCretaceous stratigraphic gap evidenced in much of the Western Pontides (Hippolyte et al., 2010). Similarly to the Western Pontides, the transgressive contact of the Kapanboğazı Formation is locally marked by a $<1 \mathrm{~m}$-thick conglomerate (along the road immediately east of site 96). Due to a compressional fault, at site 96 this unconformity is visible twice along the road, and the basal conglomerate is mainly preserved as tectonic slices in the shear zone (Fig. 11).

After this fault, the 30 m-thick Kapanboğazı Formation is overlain by the Yemişliçay Formation, which includes siliciclastic and carbonate flysch with clasts of serpentinite. In the Yemişliçay Formation, debris flow intercalations and mud balls of red 
limestone similar to the Kapanboğazı limestone suggest syndepositional tectonic deformation (Fig. 11d and e). Also, the thickness of the Yemişliçay Formation is about 80 $\mathrm{m}$, which is considerably less than in the Soğuksu-1 well (1935 m, Fig. 5b). The southward decrease in thickness of the Yemişliçay Formation continues at site 147 (Fig. 5a) where this volcanic-sedimentary sequence is only about $20 \mathrm{~m}$ thick and the Kapanboğazı limestone is $20 \mathrm{~cm}$ thick (Fig. 12). The northward increase of thickness of the Santonian-Lower Campanian sequence, from $20 \mathrm{~m}$ to about $2000 \mathrm{~m}$, resulted from the subsidence of the Sinop-Boyabat basin during the Late Cretaceous (Fig. 6). This subsidence could be either of thermal origin, postdating rifting as first proposed for the Western Pontides by Görür (1988; 1997), or it could be of tectonic origin.

In the Boyabat Sinop we interpret the thickness variations of the Kapanboğazı and Yemişliçay Formations as consequences of normal faulting during the SantonianEarly Campanian (Fig. 6b). This interpretation is motivated by the field observation of normal faults in all of the Upper Cretaceous-Paleocene sequence. We found normal faults in the Santonian-Lower Campanian Yemişliçay Formation at sites 73 and 74 (Fig. 3 and 13), within the Lower and Upper Campanian flysch of the Gürsökü Formation at sites 32 and 39 (Fig. 3 and 14), and also within Upper Paleocene carbonate flysch of the Akveren Formation at site 16 (Fig. 3 and 15). In all cases the fault diagrams indicate conjugate normal faulting predating the tilt of the stratigraphic layers, which is generally related to folding during the Eocene shortening phase (Fig. 13, 14, 15). The direction of extension in the Santonian to Paleocene rocks is ENE-WSW (Fig. 13, 14, 15). This is the same trend of extension as during the Early Cretaceous extension (Fig. 7, 9b). We conclude that ENE-trending extension characterized this part of the Black Sea margin during much of the Early Cretaceous to Late Paleocene time (Fig. 16). The compressional inversion of the extensional structures did not start before the Late Paleocene, in agreement with the Eocene age of the Boyabat compressional basin, and with fission track analysis (Espurt el al. 2014).

The Sinop Range is cut by E-W north-verging thrusts that correspond to the eastward prolongation of the Çangaldağı structural high (Fig. 3). These thrust structures are well exposed in the Gürsökü Formation along the western Sinop-Boyabat road. We observed shear zones with top to the north displacements at site 90 (Fig. 3 and 17), a pop-up structure at site 55 (Fig. 18), imbricates with out-of-sequence thrusts at sites 53 (Fig. 19) and thrusts at sites 54 and 50 (Fig. 19, 20). In agreement with the paleostress map (Fig. 3), most faults indicate a NNE-trending shortening with top to the north thrust movements (Fig. 17, 19, 20). The only exception is the NE-trending pop-up structure of site 55 (Fig. 18), which could have resulted from the recent NW-SE compression compatible with the dextral slip of the North Anatolian Fault (Fig. 4).

\section{e) Northern part: the leading edge of the thrust belt and the Sinop basin}

The northern flank of the range is characterized at depth by south-dipping inverted normal faults that were responsible for the northward thickening of the Upper Cretaceous sequence as shown by the Erfelek-1 well (Fig. 6a). These crustal faults branch upwards into a thin-skinned thrust systems with back thrusts, and flat and ramp geometries. Taking into account the flat and ramp thrust fault geometry and the conclusion from the Eocene Boyabat basin that the Eocene was a period of shortening, we interpret the Erfelek syncline (Görür and Tüysüz 1997), located above a flat thrust, as an Eocene piggy-back basin (Fig. 5c). This basin is bordered to the north by the mainly 
north-verging Balıfakı thrust system, and to the south by the Erikli back-thrust system (Fig. 6a).

The Balıfakı thrust system is an imbricate fan cutting the Eocene-Miocene sequences of the southern edge of the Sinop basin (Fig. 5c). Seismic lines show probable growth strata in the Miocene shallow marine sequence suggesting that this thrust system was also active during the Miocene. The Miocene sequence is exposed at the entrance to Sinop city (site 7, Fig. 3) where we found an ENE-trending sinistral strike-slip fault supporting this interpretation of compressional tectonics occurring during the Miocene.

The Erikli back-thrust system was observed at sites 15 and 26 (Fig. 5b, 21, 22). At this place a sharp break-in-slope suggests the presence of a north-vergent thrust, which is the interpretation given on geological maps and on cross sections (Aydin et al. 1995, Görür and Tüysüz 1997; Uğuz, et al. 2002; Yıldırım et al. 2011). However, at these localities all of the observed structures are south-vergent. These structures are compatible with NNE-SSW shortening (Fig. 3, 21, 22). These north-dipping thrust faults, in contrast to the major south-dipping thrust faulting of the northern slope of the Sinop Range, reveal the passive roof thrusting of the Erikli triangle zone (Fig. 5b, 6a).

The Balıfakı thrust system and the Erikli back-thrust system, extend WNW-ESE along the strike of the Pontides into offshore areas (Fig. 3). Coastal exposures allowed fault planes to be measured. For both thrust systems the striations correspond to NNESSW compression (sites Sinop1 and Sinop3, Fig. 3).

To the north, the Sinop Basin unconformably overlies a $40 \mathrm{~km}$-long horst-like structure, mainly composed of Upper Cretaceous volcanic rocks with a magmatic arc signature (Fig. 5c). This basin was filled by Eocene turbidites and Miocene strata (Yılmaz et al. 1997). The above mentioned growth strata in the Miocene sequence suggest that the Eocene sequence of the Sinop basin was tilted by the Balıfakı thrust system during the deposition of the Miocene clastic wedge (Fig. 5c, 6a).

\section{V- Synthesis and geodynamic implications}

The structures studied along the Sinop-Boyabat section confirm that the Central Pontide belt is a doubly-vergent thick-skinned orogenic wedge (Görür and Tüysüz 1997; Robinson and Kerusov 1997; Yıldırım et al. 2011). Its doubly-vergent geometry mainly resulted from the inversion of normal faults. Similar structural inversions seem to be common along the margins of the western Black Sea Basin during the Eocene-Miocene times, as suggested by seismic lines interpretations offshore Crimea and Romania (Khriachtchevskaia et al. 2010; Munteanu et al. 2011). In Turkey, our paleostress analysis, structural analyses, and new stratigraphic ages, provide new information on the timing and signification of the normal faulting and structural inversion events.

\section{a) Normal faulting}

Field data (Fig. 7, 9, 13, 14, 15) and thickness variations deduced from well data (Fig. 6) support the interpretation that extensional tectonics occurred in the Sinop area from the Early Cretaceous (Aptian) to the Late Paleocene. The main normal faults trend NW-SE: the Boyabat fault, Ekinveren fault, South Erikli fault and Balifaki fault (Fig. 23). The trend of extension was ENE-WSW all along the cross section (Fig. 16) and did not change with time. This suggests that the Early and Late Cretaceous-Paleocene normal 
faulting occurred during the same geodynamic process as led to the opening of the Black Sea Basin above a mid-crustal detachment (Fig. 6; Espurt et al. 2014).

Nannoplankton assemblages from Okay et al. (2006) and this study (Fig. 2) reveal that the Middle-Cretaceous stratigraphic gap evidenced in the Western Pontides (Hippolyte et al. 2010) also exists in the Central Pontides (Fig. 11). Our cross section shows that major tectonic subsidence occurred during the Early Cretaceous in the Cretaceous Boyabat basin, and then moved to the Sinop-Boyabat basin after the Coniacian (Fig. 6b). We are unable to conclude that during the Early Cretaceous there was no large subsidence below the Sinop basin because we have no well information on the thickness of the Cretaceous sequence in this area (Fig. 6). However, it is clear from the field data that in contrast with the Sinop-Boyabat basin the Cretaceous Boyabat basin was characterized by low subsidence during the Upper Cretaceous (Fig. 12). Finally, stratigraphic data, field structural data and subsurface data show that during the extensional period there were two phases of normal faulting in the Central Pontides (Aptian, and Santonian-Paleocene) and a northward shift of the main extensional subsidence.

The Mid-Cretaceous interruption of normal faulting and subsidence in the Boyabat basin was probably related to its proximity with the Lower Cretaceous accretionary complex (Fig. 1; Okay et al. 2006; 2013). The Cretaceous Boyabat basin is the eastern continuation of the Ulus basin. These are both deep flysch basins that were located close to the subduction zone during the Early Cretaceous (Fig. 1) (Hippolyte et al. 2010). Although there was not yet a volcanic arc in this area during the Early Cretaceous, their location and structure allow us to interpret them as forearc basins. Their evolution from deep flysch basin during the Aptian, to sub-aerial erosion during the Middle Cretaceous, is unexpected considering the models of Early Cretaceous rifting (e.g. Görür et al. 1993). The Mid-Cretaceous (uppermost Albian-Coniacian) stratigraphic gap and erosion were first identified in the Western Pontides (Hippolyte et al. 2010). In this area it was not clear if the uplift resulted from the rifting of the Black Sea or from the collision of the Kargı continental block (Okay et al. 2006; Hippolyte et al. 2010). Considering that the stratigraphic gap is larger in the Ulus and Boyabat forearc basins than in the Western Pontides (where Albian rocks are present), we prefer a collisional model to interpret the Mid-Cretaceous erosion (Okay et al. 2006; Hippolyte et al. 2010). The Mid-Cretaceous uplift and erosion of the Central Pontides may have resulted either from the collision of the Kargı continental block (Okay et al. 2006) or from the collision of oceanic volcanic arcs and plateaus with the Eurasian margin (Okay et al. 2013).

In contrast to the strong tectonic deformation of the accretionary wedge (Daday Massif Fig. 1, Okay et al. 2013), the Boyabat basin apparently only underwent large wavelength uplift during the Middle Cretaceous. Along our section, we have not found compressional faulting related to this event. The uplift and erosion of both the Cretaceous Boyabat basin (Fig. 6b) and the accretionary prism, explains the clasts of serpentinite observed in the Yemişliçay Formation at site SI-96 (Fig. 11).

Following the collisional event, normal faulting resumed in the Sinop-Boyabat basin, with the same ENE-WSW trend of extension (Fig 16). In the Central Pontides, the ENE-WSW trend of extension (Fig. 16) is oblique to the axis of the Cretaceous-Paleogene Sinop-Boyabat basin (ESE-WNW, Fig. 1) and to the normal faults (Fig. 23). The Cretaceous basins opened with an oblique dextral kinematics. It is not clear whether this obliquity was related to the geodynamics of the subduction zone or to the opening of 
the Black Sea Basin, or both. However, it is noticeable that extensional deformation in the forearc basins lasted until the Paleocene similar to the normal faulting in the Black Sea Basin (Robinson et al. 1996). Moreover the ENE-WSW trend of extension seems to be compatible with the opening of the eastern part of the Western Black Sea Basin and Sinop through offshore Sinop (Fig. 1). Consequently, fault kinematic analysis supports the interpretation that the Cretaceous-Paleocene normal faults of the Sinop-Boyabat forearc basin, and the normal faults of the Black Sea Basin, branch on a same midcrustal detachment (Espurt et al. 2014; Fig. 6), which would extend below the Andrusov Ridge (Robinson et al. 1996).

The unconformity between the Çağlayan and the Kapanboğazı Formations has long been interpreted as representing the syn-breakup unconformity between synrift and postrift sequences (e.g. Görür et al. 1993; Tüysüz et al. 2012). We show that in the Central Pontides extensional deformation started in the Aptian and continued through the Paleocene. Normal faulting along the Black Sea was not restricted to the Early Cretaceous (Görür 1988; 1997) or to the Cenomanian-Santonian (Tüysüz 1999; Tüysüz et al. 2012). This suggests that as for other back-arc basins (e.g. Tyrrhenian, Aegean) back arc extension in the Black Sea Basin occurred during much of the subduction activity period (Early Cretaceous-Paleocene). Our structural analysis shows that the distinction between syn-rift and post-rift sequences is not always feasible in the Black Sea area.

\section{b) Structural inversion}

Orogenic deformation in the Central Pontides is thought to have occurred during Paleocene or Eocene time (e.g. Okay and Tüysüz 1999; Kaymakci et al. 2003 a, b; Hippolyte et al. 2010; Meijers et al. 2010). Our paleostress analysis shows that in the Central Pontides deformation changed from extensional (Fig. 16) to compressional (Fig. 3) after the deposition of the Akveren Formation of Late Paleocene age (site 16, Fig. 15). We infer that structural inversion did not start in the Sinop Range before the Eocene. This conclusion is also supported by the Early Eocene (NP12, Fig. 2) onset of deposition in compressional basins located on top of thrust sheets (Erfelek basin, Fig. 2 and $5 c$ site 11, Table 1) or at the thrust front (Boyabat basin and Sinop basin, Fig. 5a and 5c). An Early Eocene time of onset of compression is also in agreement with apatite fission track analysis, providing a minimum age of cooling related to the growth of the Sinop Range at ca. $55 \pm 5 \mathrm{Ma}$ (Espurt et al. 2014).

The growth of the Sinop Range was recorded by clastic sedimentation in the Boyabat, Erfelek and Sinop basins (Fig. 23). The Sinop compressional basin is filled by Eocene-Miocene sediments. It extends for more than $240 \mathrm{~km}$ along the Black Sea coast and the Pontides (Fig. 1). To the west, its equivalent in the Western Pontides is the 130 $\mathrm{km}$-long Bartın Eocene basin (Fig. 1). To the south of the Sinop Range the Eocene Boyabat basin is the lateral equivalent of the Kastamonu and Karabük Eocene basins (Fig. 1). Both the Boyabat and the Sinop syn-compressional basins are asymmetric structures bounding thrusts of the Sinop Range on one side, and characterized by stratigraphic onlap on the opposite side (Fig. 6). This asymmetry, their location on the sides of the doubly vergent structural wedge and their sedimentary sequence that thins away from the mountain belt are characteristics shared with peripheral foreland basins (e.g. Naylor and Sinclair 2008). This suggests that the Sinop and the Eocene Boyabat compressional basins primarily resulted from lithospheric flexure during the EoceneMiocene building of the Central Pontides. 
Marine sedimentation lasted until the Bartonian in the Kastamonu and Karabük basins (nannoplankton zone NP17, Hippolyte et al. 2010; Fig. 1). We infer that even if shortening started in the Early Eocene, the main uplift of the coastal mountain ranges of the Pontides occurred after the Middle Eocene. The Oligocene (?)-Miocene growth strata of the Sinop basin support the interpretation that shortening continued until Middle Miocene time (Fig. 5c).

The above conclusion is also supported by the paleostress evolution. The structural inversion of the Cretaceous-Paleocene basins occurred under a NNE-SSW trending compression (Fig. 23). This trend of compression is consistent with the collision and indentation of the Pontides by the Kırşehir continental block (Fig. 1; Kaymakci et al. 2003 a). However, this trend of compression is not compatible with the dextral slip of the North Anatolian Fault, immediately south of our study area, which trends E-W (Fig. 1). We have showed that a more recent compression, trending NW-SE, and compatible with the dextral slip of the North Anatolian Fault, occurred after the NNE-SSW main compression (Fig. 4, 23). The change from NNE-trending compression to the recent NWtrending compression probably occurred after the Middle Miocene because the ENEtrending sinistral strike-slip fault, observed at site 7 and compatible with the first (NNEtrending) compression, cuts Middle-Upper Miocene rocks (Fig. 3). A post-Middle Miocene age of the NW-trending compression agrees with the start of westward escape of Anatolia between the Middle Miocene and the Pliocene (e.g. Facenna et al. 2006).

The NW-SE recent shortening can be correlated with the regional uplift of the northern margin of the Central Anatolian Plateau as revealed by river incision studies along the NE-SW trending strand of the Ekinveren fault south of Devrekani (Fig. 1; Yıldırım et al. 2011; 2013). However, in our study area the recent NW-SE shortening was mainly found at three sites located south of the Ekinveren thrust (Fig. 3). Fold trends and fault kinematic analysis at the leading edge of the Ekinveren and North Boyabat thrusts indicate that they moved during the Eocene-Miocene NNE-SSW shortening (Fig. 10). Along our cross section we did not find evidences for their recent reactivation under the NW-SE Late Neogene-Quaternary compression. In the study area, the modern NWSE shortening is probably accommodated along en-echelon folds as proposed by Andrieux et al. (1995) for the Miocene period (Fig. 23). Most of the structures of the Sinop Range formed from Eocene to Miocene as a result of NNE-SSW compression and were not reactivated by the recent NW-SE shortening (Fig. 23). Fault sites 19, 7 and 5 (Fig. 4), and the high elevation of alluvial fans in the Boyabat Eocene basin, support the interpretation that, in the study area, active deformation mainly occurs south of the Ekinveren thrust (Fig. 23).

Finally, our kinematic study shows that the section between Sinop and Boyabat is ideally oriented to quantify the shortening of the Central Pontides and to restore its geometry before the compressional deformation. Using a pin line ahead of the northernmost thrust front, the Balıfakı thrust (Fig. 6), the length of the Paleocene reconstructed section is $98 \mathrm{~km}$, and the modern length is $70.5 \mathrm{~km}$. The $\sim 27.5 \mathrm{~km}$ of crustal shortening corresponds to $\sim 28 \%$ of shortening along the section (Fig. 6 ). As this shortening occurred during about $40 \mathrm{Ma}$, the average deformation rate was about 0.7 $\mathrm{mm} / \mathrm{yr}$ along our section.

\section{VI- Conclusions}


The doubly vergent thick-skinned structure of the Central Pontides resulted from the inversion of Cretaceous to Paleocene normal faults. On its northern side, this thickskinned deep structure passes upwards into thin-skinned thrust systems with a piggyback basin (Erfelek) and a foreland basin (Sinop). The age of these basins and fault kinematic analyses support an Eocene to Middle Miocene age for this mountain belt (Fig. 23).

The combination of structural field data, fault kinematic data, paleostress analysis, stratigraphic data and nannoplankton age determinations, coupled with cross section restoration allows the recognition of two extensional periods followed by two compressional events in the Central Pontides.

(1) A first extensional deformation formed the Boyabat and Ulus forearc basins during Early Cretaceous time. On the Boyabat-Sinop section the normal faults dip to the north and probably branched on a north dipping mid-crustal detachment (Espurt et al. 2014). A similar northfacing fault geometry probably existed for the Ulus basin, characterized by a northward stratigraphic onlap of the Lower Cretaceous sequence (Fig. 1; Hippolyte et al. 2010).

(2) After Middle Cretaceous uplift and erosion of part of the Boyabat and Ulus forearc basins (Hippolyte et al., 2010), probably related to the collision of an oceanic plateau (Okay et al. 2013), extension resumed within the Sinop-Boyabat basin on southdipping normal faults (Fig1 and 6b). In the study area, the trends of extension were the same before and after the Mid-Cretaceous uplift (ENE-WSW), suggesting that the collision of an oceanic plateau occurred during a persistent Barremian-Paleocene extensional process. The restored section and the stratigraphic data, however, reveal a northward migration of the extensional subsidence during the Cretaceous. Following Espurt et al. (2014) we believe that extensional deformation in the Boyabat and SinopBoyabat forearc basins was related to the opening of the Black Sea Basin through a midcrustal detachment (Fig. 6).

(3) Starting in the Early Eocene, the structural inversion of the extensional basins relates to the collision and indentation of the Pontides by the Kırşehir continental block (Kaymakci et al. 2003a). This compressional phase probably lasted until the Middle Miocene.

(4) In Turkey the Late Neogene neotectonic period was characterized by the westward escape of Anatolia. In the study area, this last event is characterized by NW-SE compression, mainly localized in the Eocene Boyabat basin (Fig. 23). This trend of compression is in strong contrast with the NNE-trend of the Eocene-Miocene shortening. However, most of the compressional structures of the Pontides that formed during the Eocene-Miocene, are oblique to this compression, and were not reactivated. We infer from the rotation of the compression from NNE-SSW to NW-SE, that the transition from the collision and indentation of the Pontides by the Kırşehir continental block to the westward escape of Anatolia occurred after the Middle Miocene.

\section{ACKNOWLEDGMENTS}

This work was supported by Darius program sponsored by bhpbiliton, BP, CNRS-INSU, ENI, Maersk Oil, Petronas Garigali, Shell, Statoil, Total and the University Paris-6. Midland Valley is acknowledged for providing academic license of "Move2013" for structural modeling. We thank M. Ozkaptan for field assistance. We acknowledge the 
reviewers, Amaury Pourteau and Douwe van Hinsbergen, for their useful comments and suggestions that contributed to the improvement of the original manuscript. We are grateful to the editors W.C. Dullo and A.H.F. Robertson for their interest in this paper. CEREGE is part of the OSU-Institut Pythéas. 


\section{Figure Captions}

Fig. 1 Geological sketch of the Western and Central Pontides with location of the study area and of the cross section (modified from Aksay et al., 2002; Uğuz, et al. 2002). The inset shows the main tectonic elements of the Black Sea region (modified after Robinson et al. 1996; Robinson 1997; Okay and Tüysüz 1999). The Domuzdağ complex is part of a Lower Cretaceous accretionary wedge (Okay et al. 2006). The Boyabat flysch basin and its western prolongation the Ulus flysch basin are interpreted as forearc basins. The Araç Daday line, interpreted as the suture between the Istanbul Zone and the Sakarya Zone (Okay 1989, Okay et al. 2013), is traditionally taken as the limit between the Western Pontides and the Central Pontides (e.g. Tüysüz 1999)

Fig. 2 Stratigraphy of the study area according to 32 new nannoplankton ages (Table 1). A Mid-Cretaceous gap found first in the Western Pontides (Hippolyte et al. 2010) also exists in the Central Pontides. Similarly to the Western Pontides, sedimentation in the syn-compresional Cenozoic basins (Boyabat and Sinop) started in the Early Eocene (nannoplankton zone NP12).

Fig. 3 Geological map of the Sinop-Boyabat area with trends of the Eocene compression and the location of the cross section, seismic lines, wells and studied sites (modified from Uğuz, et al. 2002). The structure of the metamorphic basement south of Boyabat is from Okay et al. (2013). The numbers refer to outcrops discussed in this paper. BO8, SI95 and SI72 give location of the samples for apatite fission track analysis (cf. Espurt et al. 2014). Black and white arrows show the trends of the computed maximum horizontal stress axes $\sigma 1$ (INVD method, Angelier 1990) (cf. Schmidt diagrams of fault planes and paleostress axes in this figure and in Fig. 4). The Schmidt diagram (a) shows density contour lines of the poles of 162 bedding planes measured along the two roads Boyabat-Sinop and their cylindrical best fit analysis (Allmendinger et al. 2012). The trend of the section is only $6^{\circ}$ from this axis and close to the computed directions of compression.

Fig. 4 Fault slip analysis showing two successive phases of deformation in the Eocene rocks (sites Boya-19 and Boya-7) and the Jurassic limestone (site Boya-5): NNE-SSW Eocene compression was followed by NW-SE Late Neogene-Quaternary compression. Schmidt diagrams show fault planes with striation, bedding planes as dashed lines, and computed paleostress axes with a five-branch star for $\sigma 1$ (maximum principal stress axis); four-branch star for $\sigma 2$ (intermediate principal stress axis); three-branch star for $\sigma 3$ (minimum principal stress axis).

At site Boya-19, oblique faults of the main NE-trending compression, are conjugate reverse faults (cf. back-rotated 3d block diagram in the lowest part of the figure). Bedding planes and these faults have been tilted by a second and NNW-trending compression, (cf. upper diagrams). At site Boya-5, superposed striation confirms this chronology.

Fig. 5 Interpreted synthetic seismic reflection transects across the Pontides (modified from Espurt et al. 2014; location on Fig. 3). Seismic lines 1, 2, 3, 4 and 5 and the closest wells are projected onto the cross section trending $\mathrm{N} 24^{\circ} \mathrm{E}$. The numbers refer to 
outcrops discussed in this paper (map location on Fig. 3). Location and central/young ages of the apatite fission track samples BO8, SI95 and SI72 are given. The projected (Pjt) seven wells are: B1, Boyabat-1; B2, Boyabat-2; B3, Boyabat-3: Ek-1, Ekinveren-1; Sog-1, Soğuksu-1; Erf-1, Erfelek-1; Sin-2, Sinop-2.

Fig. $670 \mathrm{~km}$-long balanced cross section of the Central Pontides, and its restored Paleocene state before Eocene contraction and inversion (modified from Espurt et al. 2014). Normal faulting generated the Boyabat Early Cretaceous basin and the SinopBoyabat Late Cretaceous-Paleocene basin. The geometry of the basins takes into account the apatite fission track results (samples BO8, SI95 and S172). Due to probable lateral flow the crust was only area balanced. Crustal extension is modeled as having taken place on the same low-angle detachment as for the extensional structures of the Black Sea back-arc basin (cf. Espurt et al. 2014). The $28 \mathrm{~km}$ shortening mainly occurred by inversion of the Cretaceous-Paleocene normal faults.

Fig. 7 Tilted conjugate normal faults in the Lower Cretaceous Çağlayan formation at site 131 (Fig. 3). Schmidt diagrams show the fault planes and paleostress axes in their present attitude and back-tilted to their original attitude when bedding planes (dashed lines) were horizontal. Intraformational reworking, including olistoliths, suggests that the normal faulting was syndepositional during the Early Cretaceous.

Fig. 8 Fault contact between the Jurassic Inaltı limestone and the Lower Cretaceous Çağlayan flysch at site 113 (Fig. 3). (a) Schmidt diagrams of the folded normal fault in its present attitude (strike-slip) and back-tilted to its original attitude (normal fault). (b) Schmidt diagram of the reverse fault, related to the Eocene NNE-SSW shortening, cutting the normal fault at the northern edge of the Inaltı Jurassic limestone. (c) General view of the normal fault. (d) Intercalation of limestone clasts in the Çağlayan flysch. (e) Oblique slickenlines (grooves) on the folded normal fault

Fig. 9 Block diagrams illustrating the normal fault of Fig. 8 in its present attitude (a) and during deposition of the Çağlayan Formation (Aptian) (b). Borings in a limestone cobble shows that limestone clasts come from the shore erosion of the fault scarps.

Fig. 10 Kink folds at the tip of the North Boyabat thrust at site 151 (Fig 3) consistent with the NNE-SSW compression.

Fig. 11 Cretaceous section at the northern entrance of the Boyabat tunnel (site 96, Fig 3) C for Çağlayan Formation (Fig. b), K for Kapanboğazı Formation (Fig. c), Y for Yemişliçay Formation. Fig. d, debris flow intercalation with clasts of red limestone. Fig. e, similar clasts of red limestone at site 74 , showing that it was mud balls with volcanic debris stuck around. SI- refers to the sample number (c.f. Table 1). The unconformity represents a stratigraphic hiatus of the Cenomanian-Coniacian, equivalent to the MidCretaceous stratigraphic gap found in much of the Western Pontides (Hippolyte et al., 2010).

Fig. 12 Cretaceous section at site 147 (Fig 3). The dark shale of the Lower Cretaceous Çağlayan Formation is overlain by an Upper Cretaceous reduced sequence starting with 
Kapanboğazı red shales $(20 \mathrm{~cm}$ thick) and continuing with volcanic rocks of the Yemişliçay Formation ( $20 \mathrm{~m}$ thick). The Cretaceous rocks are thrust over Eocene clays along the Ekinveren thrust fault (Ek.). L. Cret. (Lower Cretaceous Çağlayan Formation), Kap. (Kapanboğazı Formation), U. Cret. (Upper Cretaceous Yemişliçay Formation).

Fig. 13 Examples of normal faults in the volcaniclastic sandstones of the Yemişliçay Formation. Schmidt diagrams of the fault planes and computed paleostress axes at sites 73 and 74 (Fig. 3).

Fig. 14 Examples of normal faults in the Campanian flysch of the Gürsökü Formation. Schmidt diagrams of the fault planes at sites 32 and 39 (Fig. 3).

Fig. 15 Normal faults in the Upper Paleocene carbonate flysch of the Akveren Formation at site 16 (Fig. 3) and corresponding Schmidt diagrams with computed paleostress axes.

Fig. 16 Cretaceous-Paleocene trends of extension ( $\sigma 3$ axis, same legend as for Fig. 3). Refer to Fig. 13 for the Schmidt diagrams of sites 73 and 74, to Fig. 9 for site 113, and to Fig. 7 for site 131. The faults of site 32 are back-tilted to their original attitude when bedding planes (dashed lines) were horizontal (compare with Fig. 14).

Fig. 17 Asymmetric shear indicating a top to the north displacement at site 90 in marls intercalated in the Gürsökü flysch (Fig. 3, 5).

Fig. 18 Pop-up structure in the Gürsökü flysch at site 55 (Fig. 3, 5). Similarly to the doubly vergent wedge of the Central Pontides, two little normal faults suggest that the pop-up structure results from the reactivation of antithetic normal faults (Fig. 6a)

Fig. 19 Compressional structures in the Campanian Gürsökü flysch at sites 54 and 53 (Fig. 3 and 5). The Schmidt diagram shows that the fault propagation fold is compatible with the general NNE-trending shortening. At site 53, imbricate thrusts (a), (b), (c), (d), (e) probably formed in a forward-breaking sequence (northward propagation). The resulting antiformal stack was cut by an out-of-sequence thrust (2). All the thrusts are north-vergent as on the seismic line (Fig. 5).

Fig. 20 North-vergent Günpınar-Dranaz thrust in the Gürsökü flysch at the eastern prolongation of the Çangaldağ High (Fig. 3 and 5)

Fig. 21 Erikli back thrust system at site 15 (Fig. 3 and 5). The Erikli thrust is interpreted as a back thrust system based on the south vergent structures observed at sites 15 and 26 (Fig. 22). South vergent thrust propagation folds are interpreted as related to the passive roof thrusting of a triangle zone (Fig. $6 \mathrm{a}$ ). The Schmidt diagram shows the poles and great circle traces of the measured bedding planes.

Fig. 22 South vergent thrust of the Erikli back thrust system at site 26 (Fig. 3). Note the fault-bend fold in the hanging wall block, and the drag folds in the foot wall block. The Schmidt diagram shows the thrust plane and the poles of schistosity planes measured in 
the shear band and consistent with the general NNE-SSW shortening. The Erikli back thrust system is related to passive roof duplexes of a triangle zone (Fig. 5 and 6)

Fig. 23 Structural evolution of the Central Pontides from Early Cretaceous to Present. From Aptian to Paleocene, ENE-trending extension, even if interrupted by a MidCretaceous (Latest Albian to Coniacian) collision, uplift, and widespread erosion, generated the Boyabat basin, then the Sinop-Boyabat basin. From Early Eocene to Middle Miocene, tectonic inversion related to continental collision uplifted the Sinop Range bounded by asymmetric syn-compressional basins. In the Late Neogene, with the initiation of the North Anatolian fault, the trend of compression rotated to NW-SE. Enechelon folds in the Boyabat basin (Andrieux at al. 1995) could result from dextral shear along this basin. Note that the normal faults are not restored to their position before shortening.

Table 1 Age and nannoplankton assemblages of the 32 dated samples. Coordinates are in UTM36.

Table 2 Paleostress tensors computed from fault-slip data and coordinates of fault sites (UTM36).

Stress regimes: $\mathrm{C}=$ compressional, $\mathrm{S}=$ strike-slip, $\mathrm{E}=$ extensional. $\sigma 1, \sigma 2, \sigma 3$ : maximum, intermediary and minimum principal stress axis respectively. tr., pl.: trend (north to east) and plunge in ${ }^{\circ}$ of the stress axes. $\Phi=(\sigma 2-\sigma 3) /(\sigma 1-\sigma 3)$. ANG $=$ average angle between computed shear stress and observed slickenside lineation $\left({ }^{\circ}\right)$. RUP = quality estimator $(0<R U P<200)$ taking into account the relative magnitude of the shear stress on fault planes (cf. Angelier, 1990). 


\section{References:}

Akbayrama K, Okay Al, Satır M (2013) Early Cretaceous closure of the Intra-Pontide Ocean in western Pontides (northwestern Turkey). Journal of Geodynamics 65:38-55

Aksay A, Pehlivan S, Gedik I, Bilginer E, Duru M, Akbas B, Altun I (2002) Geological map of Turkey 1:500 000 Zonguldak Paftası. Maden Tetkik ve Arama Genel Müdürlüğü Ankara

Allmendinger RW, Cardozo NC, Fisher D (2012) Structural Geology Algorithms: Vectors \& Tensors: Cambridge, England, Cambridge University Press, 289 pp.

Andrieux J, Over S, Poisson A, Bellier O (1995) The North Anatolian fault zone: distributed Neogene deformation in its northward convex part. Tectonophysics 243:135-154

Angelier J (1990) Inversion of field data in fault tectonics to obtain the regional stress-III. A new rapid direct inversion method by analytical means. Geophysical Journal International 103:363-376

Aydın M, Demir O, Serdar HS, Özaydın S, Harput B (1995) Tectono-sedimentary evolution and hydrocarbon potential of the Sinop-Boyabat Basin, North Turkey, In: Erler A et al. (ed), Geology of the Black Sea Region: General Directorate of Mineral Research and Exploration, Ankara, pp 254263

Aydın M, Şahintürk Ö, Serdar HS, Özçelik Y, Arkasu I, Üngör A, Cokugras R, Kasar S (1986) BallıdağÇangaldağı (Kastamonu) arasindaki bölgenin jeolojisi. Bulletin of the Geological Society of Turkey 29:1-16

Belousov VV, and 24 others (1988) Structure and evolution of the Earth's crust and upper mantle of the Black Sea: Bollettino di Geofi sica Teorica ed Applicata 30:109-196

Channell JET, Tüysüz O, Bektas O, Sengör AMC (1996) Jurassic-Cretaceous paleomagnetism and paleogeography of the Pontides (Turkey).Tectonics 15:201-212

Derman S, Sayılı A (1995) İnaltı Formation: a key unit for regional geology. In: Erler A, Ercan T, Bingöl E, Örçen S (eds) Geology of the Black Sea Region Proceedings of the International Symposium on the Geology of the Black Sea Region. Mineral Research and Exploration Institute of Turkey (MTA), pp 104-108

Elmas A, Yiğitbaş E (2005) Comment on "Tectonic evolution of the Intra-Pontide suture zone in the Armutlu Peninsula, NW Turkey" by Robertson and Ustaömer. Tectonophysics 405:213-221.

Espurt N, Hippolyte JC, Kaymakci N, Sangu E (2014) Lithospheric structural control on inversion of the southern margin of the Black Sea Basin, Central Pontides, Turkey. Lithosphere 6:26-34 doi.org/10.1130/L316.1

Eyuboglu Y, Santosh M, Dudas FO, Akaryalı E, Chung SL, Akdağ K, Bektaş O (2013) The nature of transition from adakitic to non-adakitic magmatism in a slab window setting: A synthesis from the eastern Pontides, NE Turkey. Geoscience Frontiers 4:353-375

Faccenna C, Bellier O, Martinod J, Piromallo C, Regard V (2006) Slab detachment beneath eastern Anatolia: A possible cause for the formation of the North Anatolian fault. Earth and Planetary Science Letters 242 (1-2): 85-97. ISSN 0012-821X

Finetti I, Bricchi G, Del Ben A, Pipan M, Xuan Z (1988) Geophysical study of the Black Sea. Bolletino di Geofisica ed Applicata 30:197-324

Görür N (1988) Timing of opening of the Black Sea Basin. Tectonophysics 147:247-262

Görür N (1997) Cretaceous syn- to post-rift sedimentation on the southern continental margin of the Western Black Sea Basin. In: Robinson AG (ed) Regional and petroleum geology of the Black Sea and surrounding region. AAPG Memoir 68:227-240

Görür N, Tüysüz O (1997) Petroleum geology of the southern continental margin of the Black Sea. In: Robinson AG (ed) Regional and Petroleum Geology of the Black Sea and surrounding region. AAPG Memoir 68: 53-62

Görür N, Tüysüz O, Aykol A, Sakinc M, Yigitbas E, Akkök R (1993) Cretaceous red pelagic carbonates of northern Turkey: Their place in the opening history of the Black Sea. Eclogae Geologicae Helvetiae 86:819-838

Graham R, Kaymakci N, Horn B (2013) Revealing the Mysteries of the Black Sea. GEO ExPro 5:58-63.

Hippolyte JC, Müller C, Kaymakci N, Sangu E (2010) Dating of the Black Sea Basin: new nannoplankton ages from its inverted margin in the Central Pontides (Turkey). In: Sosson M, Kaymakci N, Stephenson R, Bergerat F, Starostenko V (eds) Sedimentary Basin Tectonics from the Black Sea 
and Caucasus to the Arabian Platform. Geological Society London Special Publication 340:113-136 doi.org/10.1144/SP340.7

Hsü KJ, Nacev IK, Vuchev VT (1977) Geologic evolution of Bulgaria in the light of plate tectonics. Tectonophysics 40:245-256

Hu X, Jansa L, Wang C, Sarti M, Bak K, Wagreich M, Michallik J, Soták J (2005) Upper Cretaceous oceanic red beds (CORBs) in the Tethys: occurrences, lithofacies, age, and environments. Cretaceous Research 26: 3-20

Kaymakci N (2000) Tectono-stratigraphical evolution of the Çankiri Basin (Central Anatolia Turkey). Ph.D Thesis Geologica Ultraiectina. No. 190 Utrecht University Faculty of Earth Sciences, The Netherlands. 232p.

Kaymakci N, Duermeijer CE, Langereis C, White SH, van Dijk PM (2003a) Oroclinal bending due to indentation: a paleomagnetic study for the Early Tertiary evolution of the Çankiri Basin (central Anatolia Turkey). Geological Magazine 140:343-355

Kaymakci N, Özcelik Y, White SH, Van Dijk PM (2009) Tectono-stratigraphy of the Çankiri Basin: Late Cretaceous to Early Miocene evolution of the Neotethyan Suture Zone in Turkey. In: Van Hinsbergen DJJ, Edwards MA, Govers R (eds) Geodynamics of Collision and Collapse at the AfricaArabia-Eurasia subduction zone. Geological Society of London London Special Issue 311:67-106

Kaymakci N, White SH, van Dijk PM (2003b) Kinematic and structural development of the Çankiri Basin (Central Anatolia Turkey): a paleostress inversion study. Tectonophysics. 364:85-113

Ketin I, Gümüs Ö (1963) Sinop-Ayancik arasindaki III. bölgeye dahil sahalarin jeolojisi hakkinda rapor 2. Kisim Jura ve Kretase Formasyonlarinin etüdü. Türkiye Petrolleri Arama Grubu Arsivi (unpublished report) No. 213-288 118p.

Khriachtchevskaia O, Stovba S, Stephenson R. (2010) Cretaceous-Neogene tectonic evolution of the northern margin of the Black Sea from seismic reflection data and tectonic subsidence analysis. In: RA Stephenson et al. (eds) Sedimentary Basin Tectonics from the Black Sea and Caucasus to the Arabian Platform. Geological Society, London, Special Publications 340:137-157 doi:10.1144/SP340.8

Lefebvre C., Meijers MJM, Kaymakci N, Peynircioğlu A, Langereis CG, vanHinsbergen DJJ (2013) Reconstructing the geometry of central Anatolia during the late Cretaceous: Large-scale Cenozoic rotations and deformation between the Pontides and Taurides: Earth and Planetary Science Letters 366:83-98

Leren BLS (2003) Late Cretaceous to Early Eocene sedimentation in the Sinop-Boyabat Basin, north-central Turkey: facies analysis of turbiditic to shallow-marine deposits. PhD thesis Bergen University Norway 140p.

Leren BLS, Janbu NE, Nemec W, Kırman E, Ilgar A (2007) Late Cretaceous to Early Eocene sedimentation in the Sinop-Boyabat Basin, north-central Turkey: a deep-water turbiditic system evolving into littoral carbonate platform. In: Nichols G, Paola C, Williams EA (eds) Sedimentary Environments, Processes and Basins - A Tribute to Peter Friend. Int. Assoc. Sedimentol. Spec. Publ. 38:401-456.

Letouzey J, Bilu-Duval B, Dorkel A, Gonnard R, Kritchev K, Montadert L, Sungurlu O (1977) The Black Sea : a marginal basin; geophysical and geological data. In: Bilu-Duval B, Montadert L (eds) International Symposium on the Structural History of the Mediterranean Basins Technip, Paris, pp. 363-376

Meijers MJM, Kaymakci N, Van Hinsbergen DJJ, Langereis CG, Stephenson RA, Hippolyte JC (2010) Late Cretaceous to Paleocene oroclinal bending in the central Pontides (Turkey). Tectonics 29, TC4016, doi:10.1029/2009TC002620

Munteanu I, Matenco L, Dinu C, Cloetingh S (2011) Kinematics of back-arc inversion of the Western Black Sea Basin. Tectonics 30, TC5004, doi:10.1029/2011TC002865

Naylor M, Sinclair HD (2008) Pro- vs. retro-foreland basins. Basin Research doi: 10.1111/j.13652117.2008.00366.x

Nikishin AM, Okay A, Tüysüz O, Demirer A., Wannier M, Amelin N, Petrov E (2015) The Black Sea basins structure and history: New model based on new deep penetration regional seismic data. Part 2: Tectonic history and paleogeography. Marine and Petroleum Geology 59:656-670

Okay Al (1989) Tectonic units and sutures in the Pontides northern Turkey. In: Şengör A.M.C. (ed) Tectonic Evolution of the Tethyan Region. Kluwer Academic Publications pp. 109-116

Okay Al, Sahintürk O (1997) Geology of the Eastern Pontides, In: Robinson AG (ed) Regional and petroleum geology of the Black Sea and surrounding region. AAPG Memoir 68:291-311 
Okay Al, Şengör AMC, Görür N (1994) Kinematic history of the opening of the Black Sea and its effect on the surrounding regions. Geology 22 267-270

Okay Al, Sunal G, Sherlock S, Altiner D, Tüyzüz O, Kylander-Clark ARC, Aygül M (2013) Early Cretaceous sedimentation and orogeny on the active margin of Eurasia: Southern Central Pontides, Turkey. Tectonics 32:1-25 http://doi.org/:10.1002/tect.20077

Okay Al, Tüysüz O (1999) Tethyan Sutures of northern Turkey. In: Durand B, Jolivet L, Horvath F, Séranne $M$ (eds) The Mediterranean Basins: Tertiary extension within the Alpine Orogen. Geological Society London Special Publication 156:475-515

Okay Al, Tüysüz O, Satır M, Özkan-Altıner S, Altıner D, Sherlock S, Eren RH (2006) Cretaceous and Triassic subduction-accretion high-pressure-low-temperature metamorphism and continental growth in the Central Pontides Turkey. Geological Society America Bulletin 118:1247-1269

Pourteau A, Candan O, Oberhänsli R (2010) High-pressure metasediments in central Turkey: Constrains on the Neotethyan closure history. Tectonics 29 doi:10.1029/2009TC002650

Reilinger R, and 25 others (2006) GPS constraints on continental deformation in the Africa-Arabia-Eurasia continental collision zone and implications for the dynamics of plate interactions. Journal of Geophysical Research 111 p. B05411, doi:10.1029/2005JB004051

Rice SP, Robertson AHF, Ustaömer T, İnan N, Tasli K (2009) Late Cretaceous-Early Eocene tectonic development of the Tethyan suture zone in the Erzincan area, Eastern Pontides, Turkey. Geological Magazine 146: 567-590.

Robertson AHF, Ustaömer T (2004) Tectonic evolution of the Intra-Pontide suture zone in the Armutlu Peninsula, NW Turkey. Tectonophysics 405, 213-221.

Robinson A (1997) Introduction: Tectonic elements of the Black Sea region. In: Robinson A (ed.) Regional and petroleum geology of the Black Sea and surrounding region. AAPG Memoir 68:1-6

Robinson A, Kerusov E (1997) Stratigraphic and structural development of the Gulf of Odessa, Ukrainian Black Sea: implications for petroleum exploration. In: Robinson A (ed.) Regional and Petroleum Geology of the Black Sea and Surrounding Region. AAPG Memoir 68:369-380

Robinson A, Rudat JH, Banks CJ, Wiles RLF (1996) Petroleum geology of the Black Sea. Marine and Petroleum Geology 13:195-223

Şen, Ş (2013) New evidences for the formation of and for petroleum exploration in the fold-thrust zones of the central Black Sea Basin of Turkey. AAPG Bulletin 97, 3: 465-485. doi.org/10.1306/09041212005

Şengör AMC, Görür N, Saroglu F (1985) Strike-slip faulting and related basin formation in zones of tectonic escape: Turkey as a case study. In: Biddle KT, Christie-Blick N (eds) Strike-slip faulting and basin formation: Society of Economical Paleontologists and Mineralogists Special Publication 37: 227264

Şengör AMC, Yılmaz Y (1981) Tethyan evolution of Turkey: a plate tectonic approach. Tectonophysics 75:181-241

Şengör AMC, Yılmaz Y, Sungurlu O (1984) Tectonics of the Mediterranean Cimmerides: nature and evolution of the western termination of Palaeo-Tethys. In: Dixon JE, Robertson AHF (eds) The Geological Evolution of the Eastern Mediterranean. Geol. Soc. London Spec. Publ. 17:77-112

Sonel N, Sari A, Coşkun B, Tozlu, E (1989) Importance of Ekinveren fault in oil exploration in the Boyabat (Sinop) basin. Geological Bulletin of Turkey 32: 39-49

Stampfli GM, Mosar J, Faure P, Pillevuit A, Vannay JC (2001) Permo-Mesozoic evolution of the western Tethys realm: the Neotehys-East Mediterranean basin connection. In: P. Ziegler P, Cavazza W, Robertson AHF, Crasquin-Soleau S (eds) Peri-Tethys Memoir 6: Peri-Tethyan Rift/Wrench Basins and Passive Margins. Mém. Mus. Natl. Hist. Nat., Paris. 186: 9-50

Stephenson R, Schellart WP (2010) The Black Sea back-arc basin: insights to its origin from geodynamic models of modern analogues. In: Sosson M, Kaymakci N, Stephenson R, Bergerat F, Starostenko V (eds) Sedimentary Basin Tectonics from the Black Sea and Caucasus to the Arabian Platform. Geological Society London Special Publication 340: 11-21, doi: 10.1144/SP340.2

Stolyarov AS, Ivleva EI (2006) Lower Miocene sediments of the Maikop Group in the Cental Eastern Paratethys. Lithology and Mineral Ressources 41:54-72

Tüysüz O (1999) Geology of the Cretaceous sedimentary basins of the Western Pontides Geological Journal 34:75-93

Tüysüz O, Yılmaz IO, Svábenická L, Kirici S (2012) The Unaz Formation: a key unit in the Western Black Sea region, N Turkey. Turkish Journal of Earth Sciences 21:2012-1028 
Uğuz MF, Sevin M, Duru M (2002) Geological map of Turkey: Sinop. Scale 1:500 000. Senel M. Editor. Maden Tetkik ve Arama Genel Müdürlüğü (MTA) General directorate of Mineral Research and Exploration. Ankara Turkey

Ustaömer T, Robertson AHF (1997) Tectonic-sedimentary evolution of the North-Tethyan margin in the Central Pontides of northern Turkey in Robinson A.G. ed. Regional and petroleum geology of the Black Sea and surrounding region. American Association of Petroleum Geologists Memoir 68:255-290

Ustaömer T, Robertson AHF (2010) Late Palaeozoic-Early Cenozoic tectonic development of the Eastern Pontides (Artvin area), Turkey: stages of closure of Tethys along the southern margin of Eurasia. In: Stephenson RA et al. (eds) Sedimentary Basin Tectonics from the Black Sea and Caucasus to the Arabian Platform. Journal of the Geological Society, Special Publications 340:281-327 http://doi.org/:10.1144/SP340.13

Yiğitbaş E, Kerrich R, Yılmaz Y, Elmas A, Xie Q (2004) Characteristics and geochemistry of Precambrian ophiolites and related volcanics from the Istanbul-Zonguldak Unit Northwestern Anatolia Turkey: following the missing chain of the Precambrian South European suture zone to the east. Precambrian Research 132:179-206

Yıldırım C, Schildgen TF, Echtler H, Melnick D, Bookhagen B, Çiner A, Niedermann S, Merchel S, Martschini M, Steier P, Strecker MR (2013) Tectonic implications of fluvial incision and pediment deformation at the northern margin of the Central Anatolian Plateau based on multiple cosmogenic nuclides.Tectonics 32:1-14 doi:10.1002/tect.20066

Yıldırım C, Schildgen TF, Echtler H, Melnick D, Strecker MR (2011) Late Neogene and active orogenic uplift in the Central Pontides associated with the North Anatolian Fault: Implications for the northern margin of the Central Anatolian Plateau, Turkey. Tectonics 30 TC5005, DOI: 10.1029/2010TC002756

Yılmaz Y, Tüysüz O, Yigitbas E, Can Genç S, Sengör AMC (1997) Geology and tectonic evolution of the Pontides. In: Robinson A G (ed) Regional and petroleum geology of the Black Sea and surrounding region American Association of Petroleum Geologists Memoir 68:255-290

Zonenshain LP, Le Pichon X (1986) Deep basins of the Black Sea and Caspian Sea as remnants of Mesozoic back-arc basins. Tectonophysics 123:181-211 


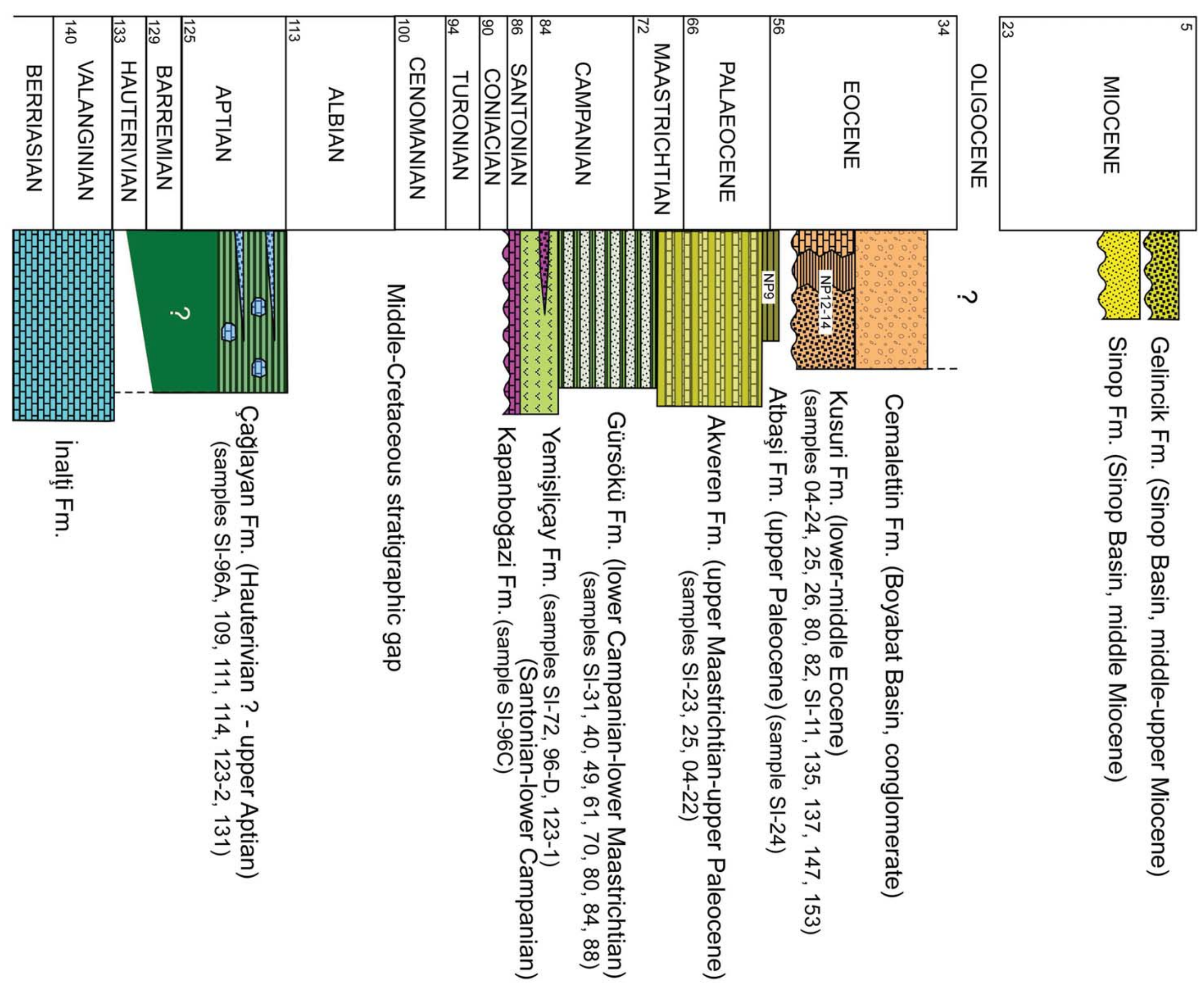












MIDDLE SI72(56.5Ma)

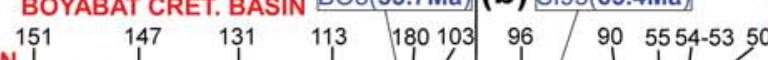
BASIN Boyabatit
fault

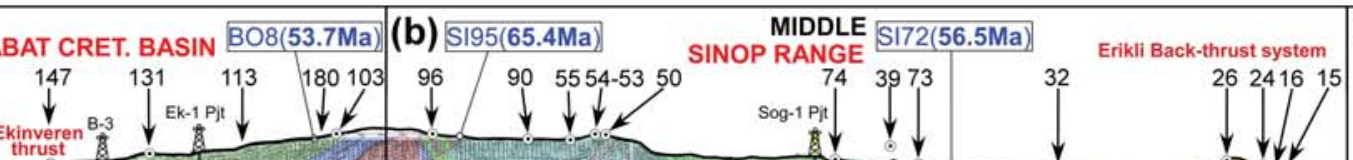
26 2416

(c)

Boy

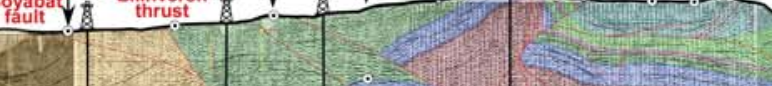

.



Ert-1 Errelek syncline Balifaki thrust system

Growth strata

SINOP BASIN

North Sinop $D c b$ ?
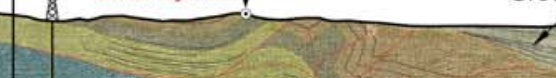

1

Sinop horst

Jura. metamorphic units (Cangaldag complex+Akgal) line 2 L L L L 

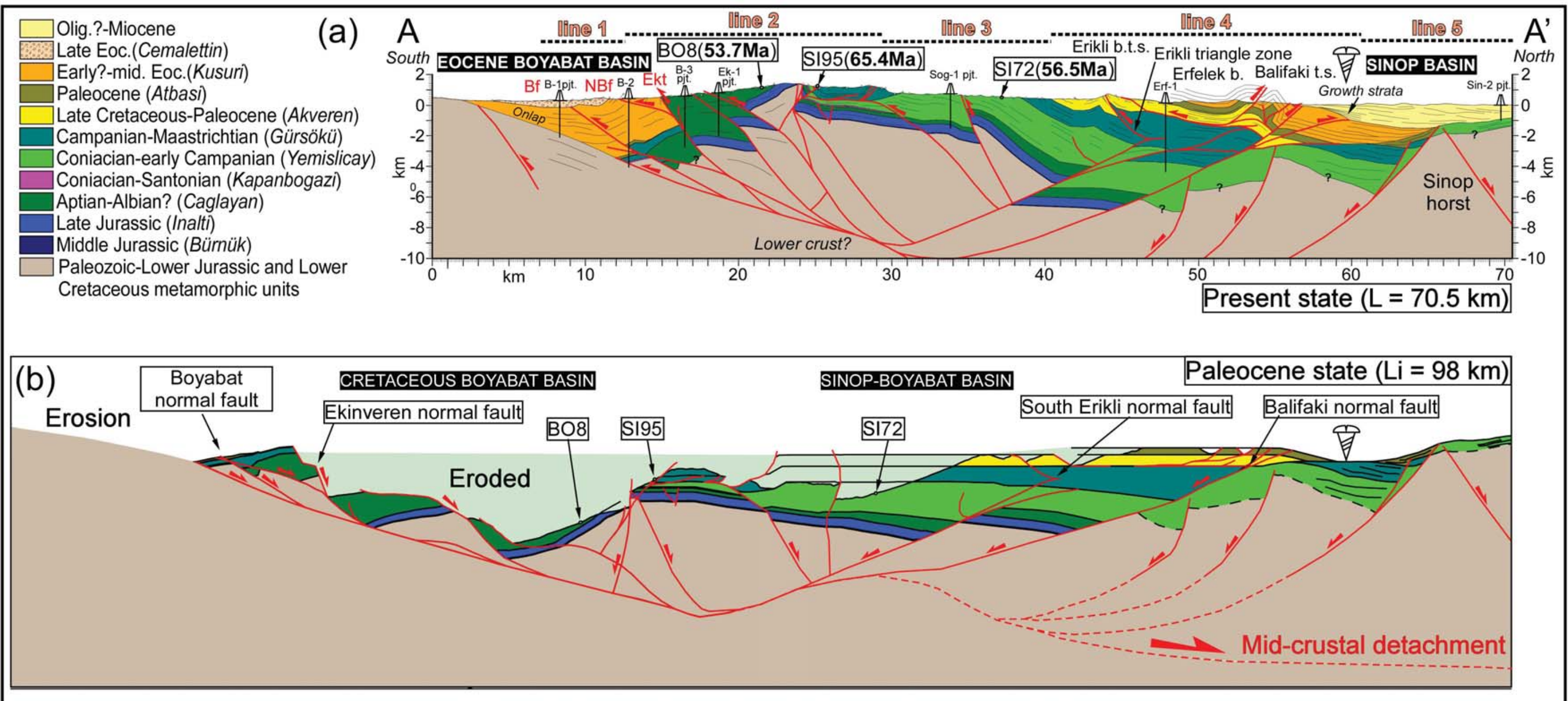







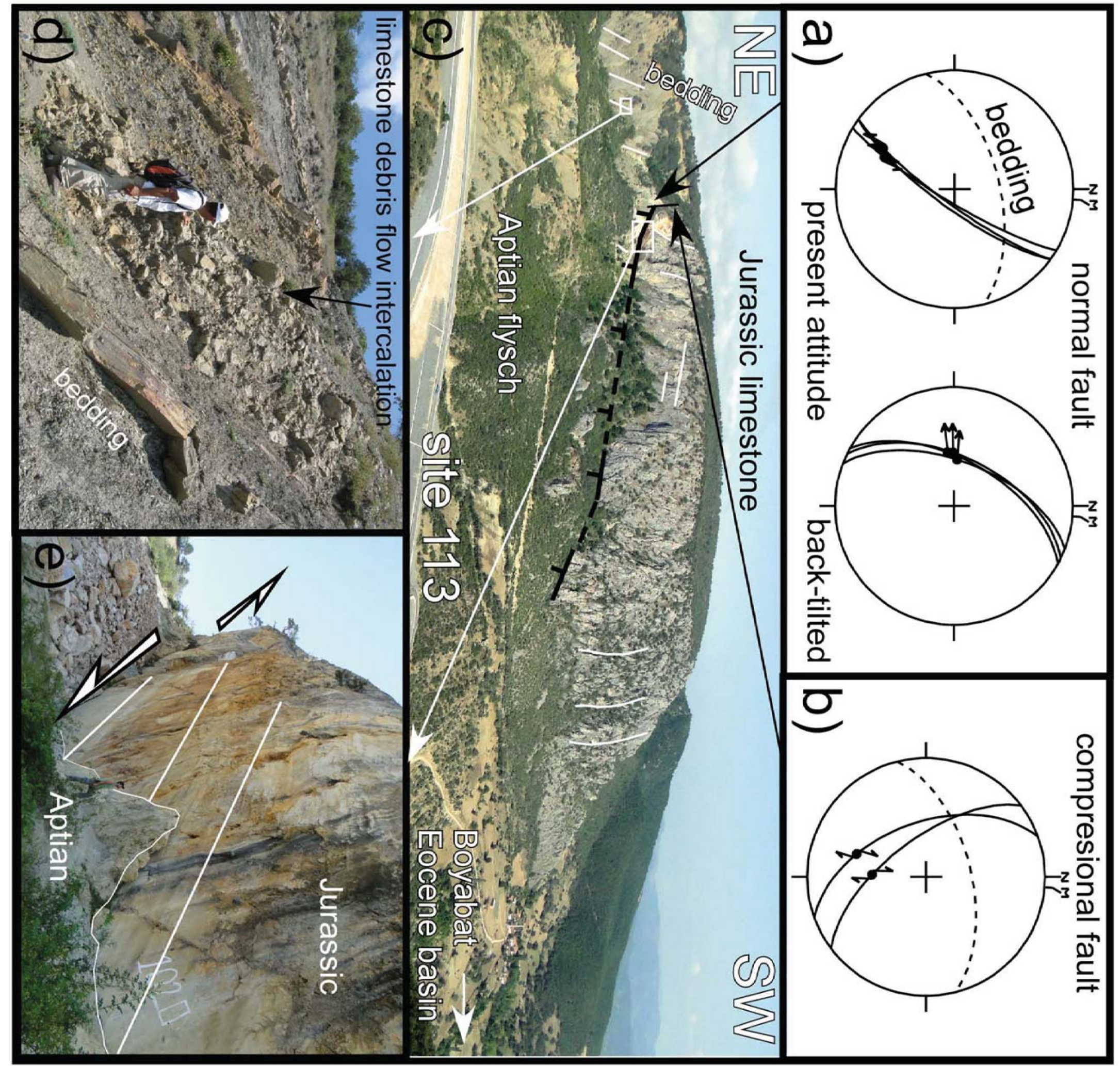




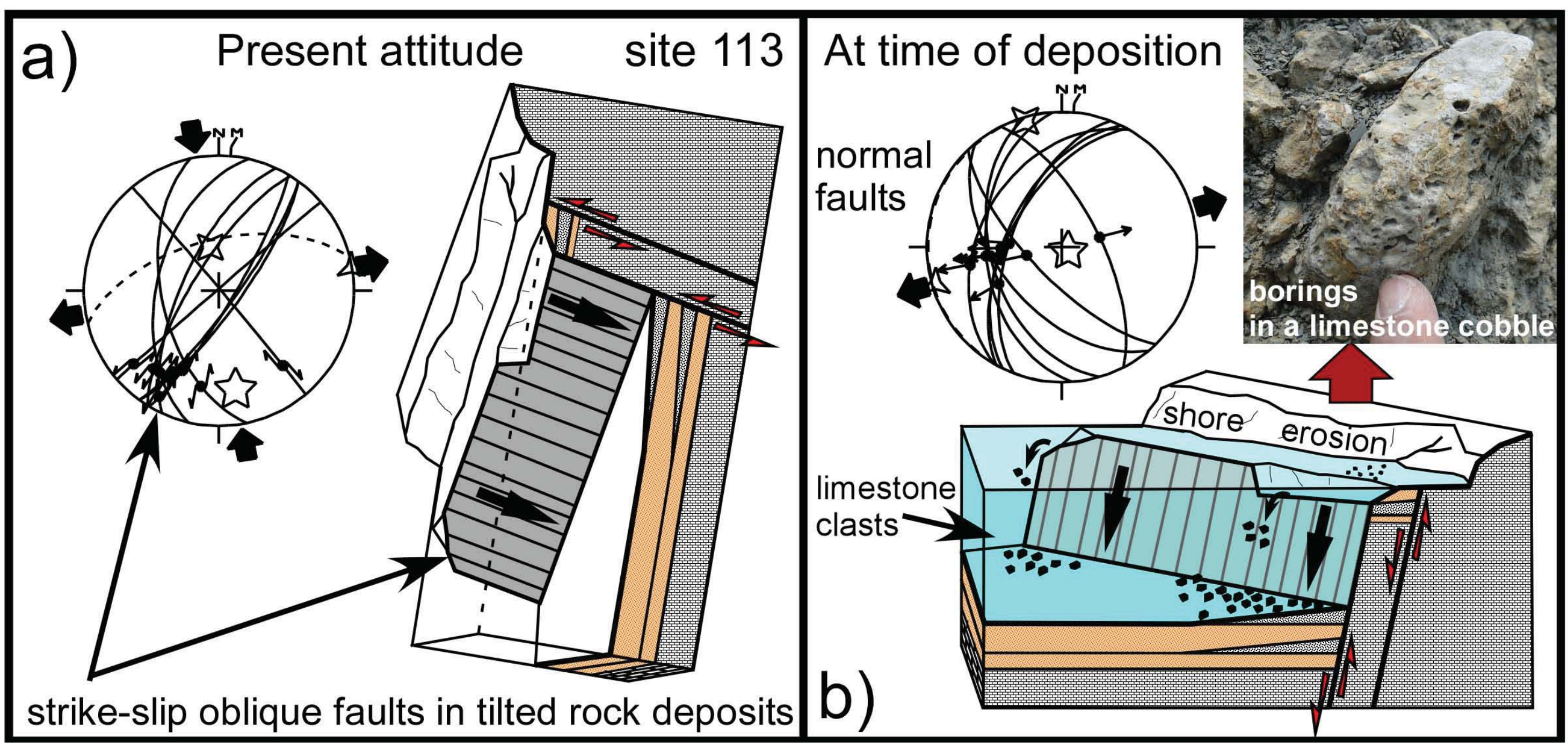




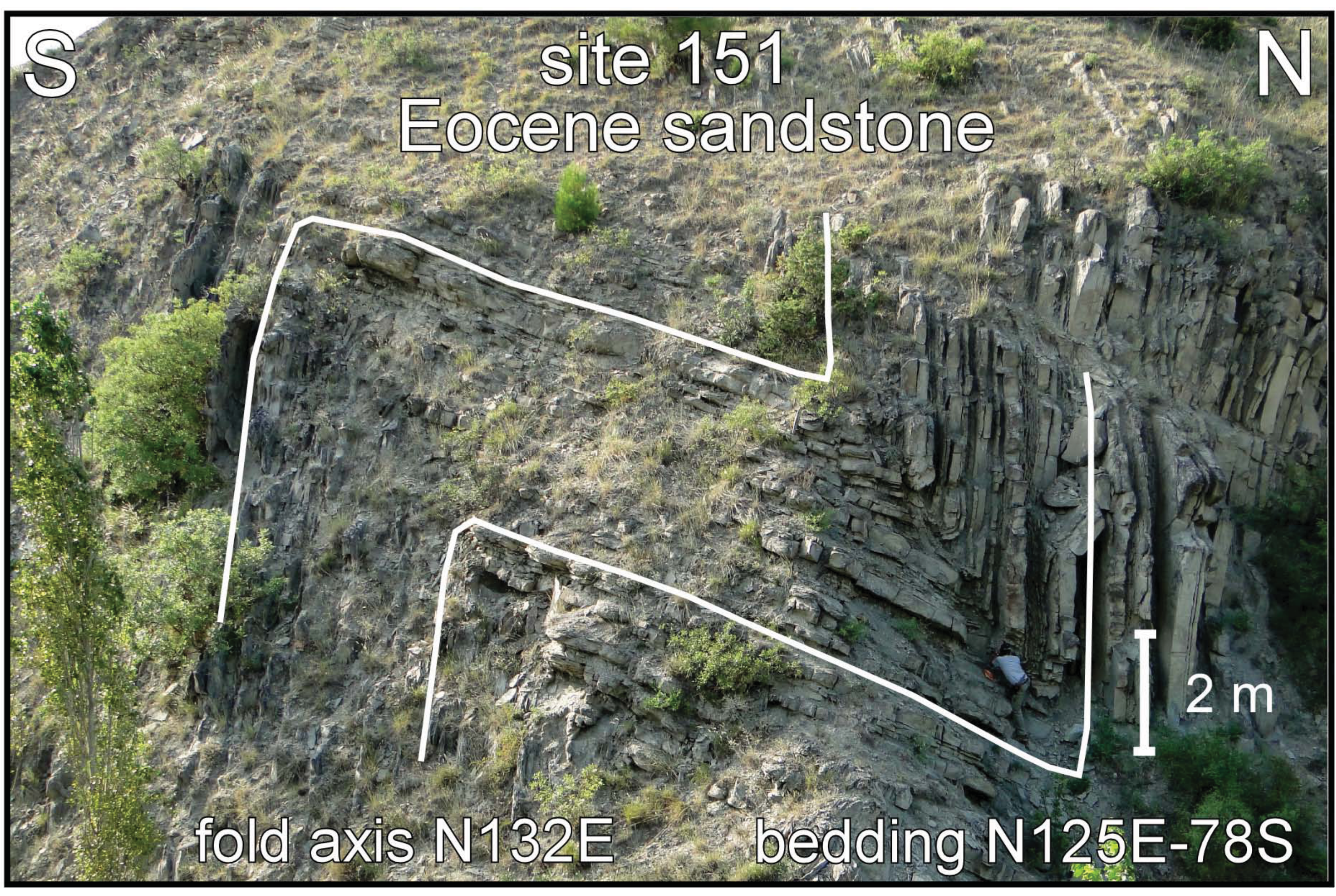




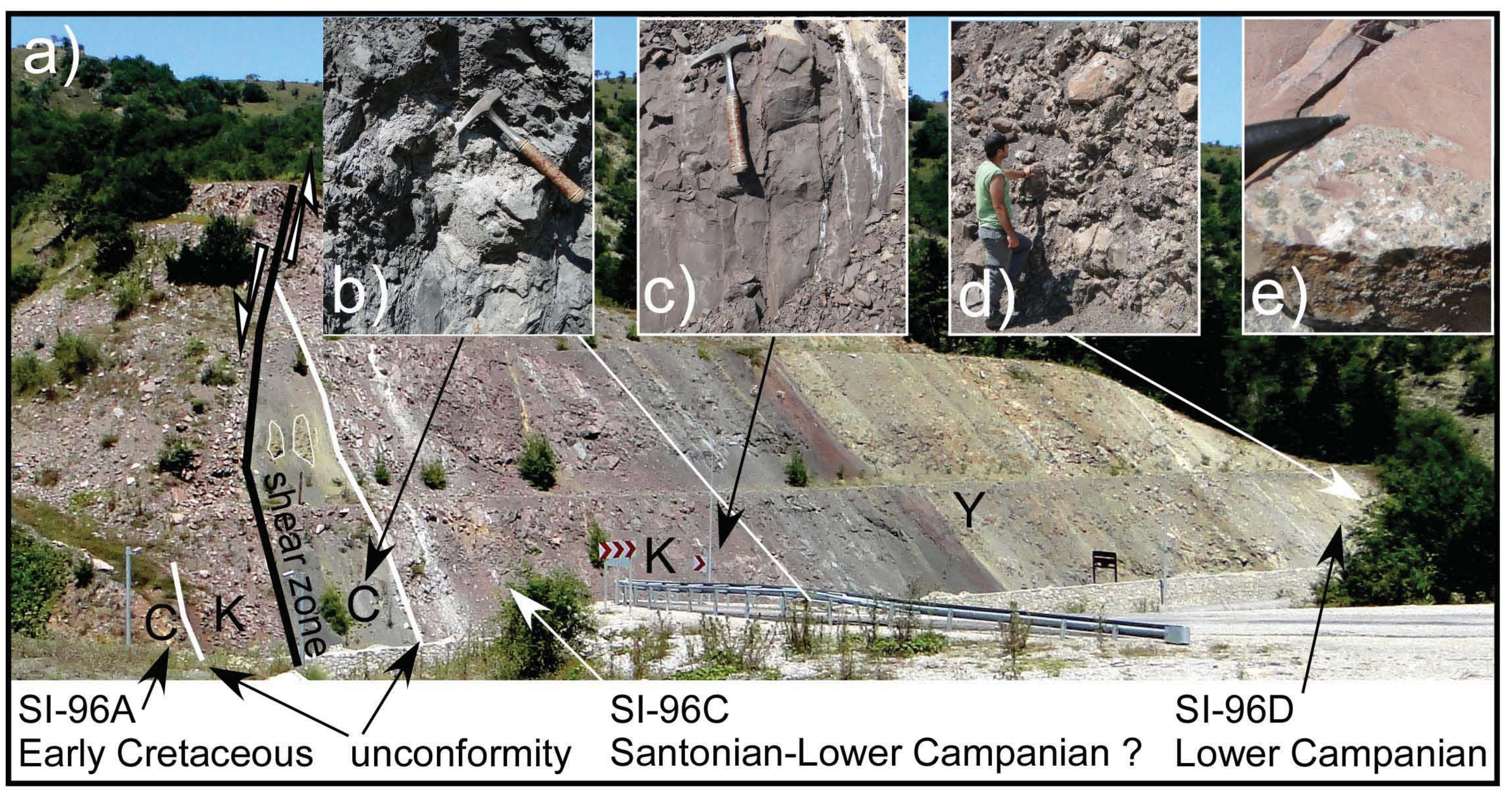









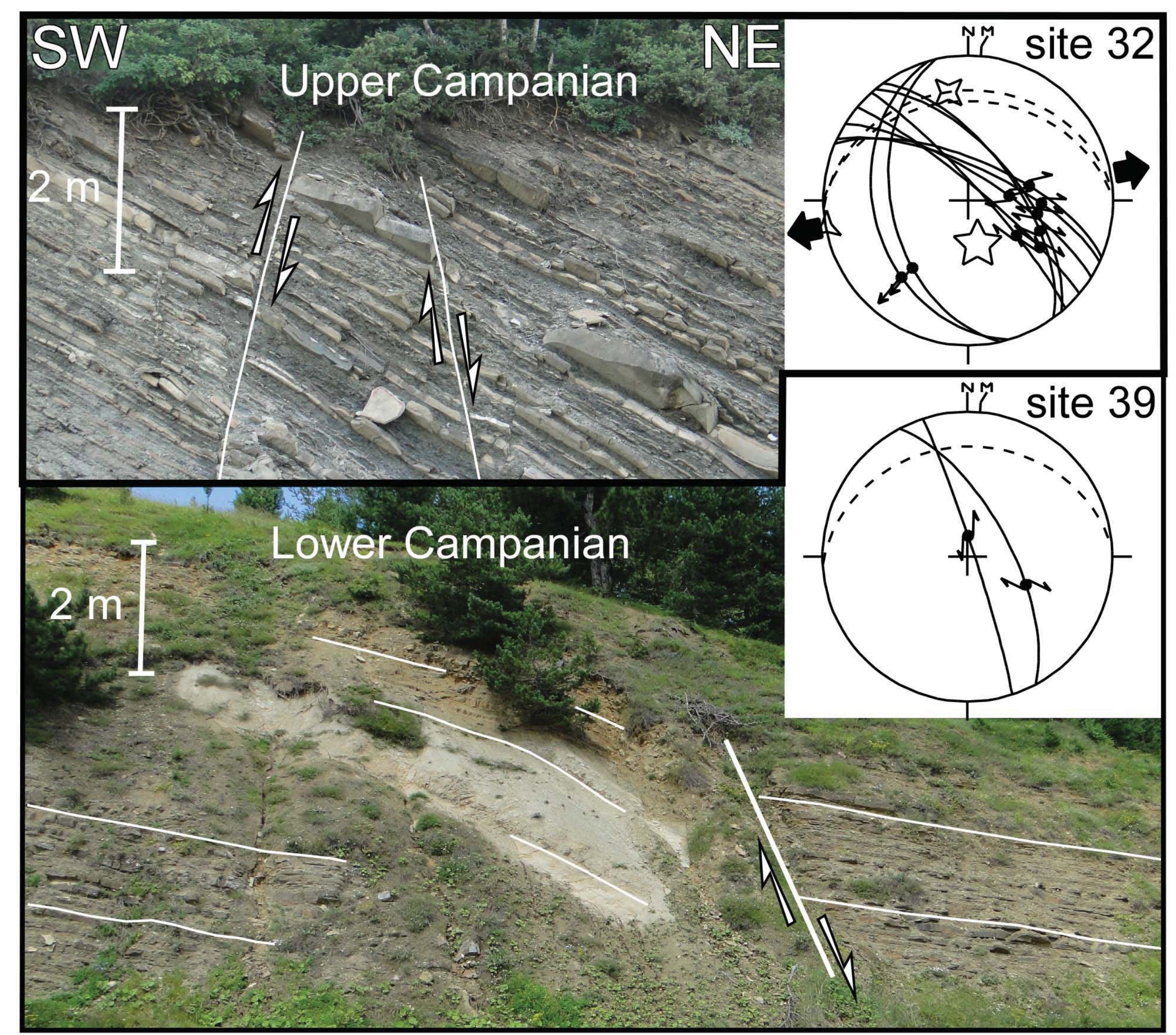









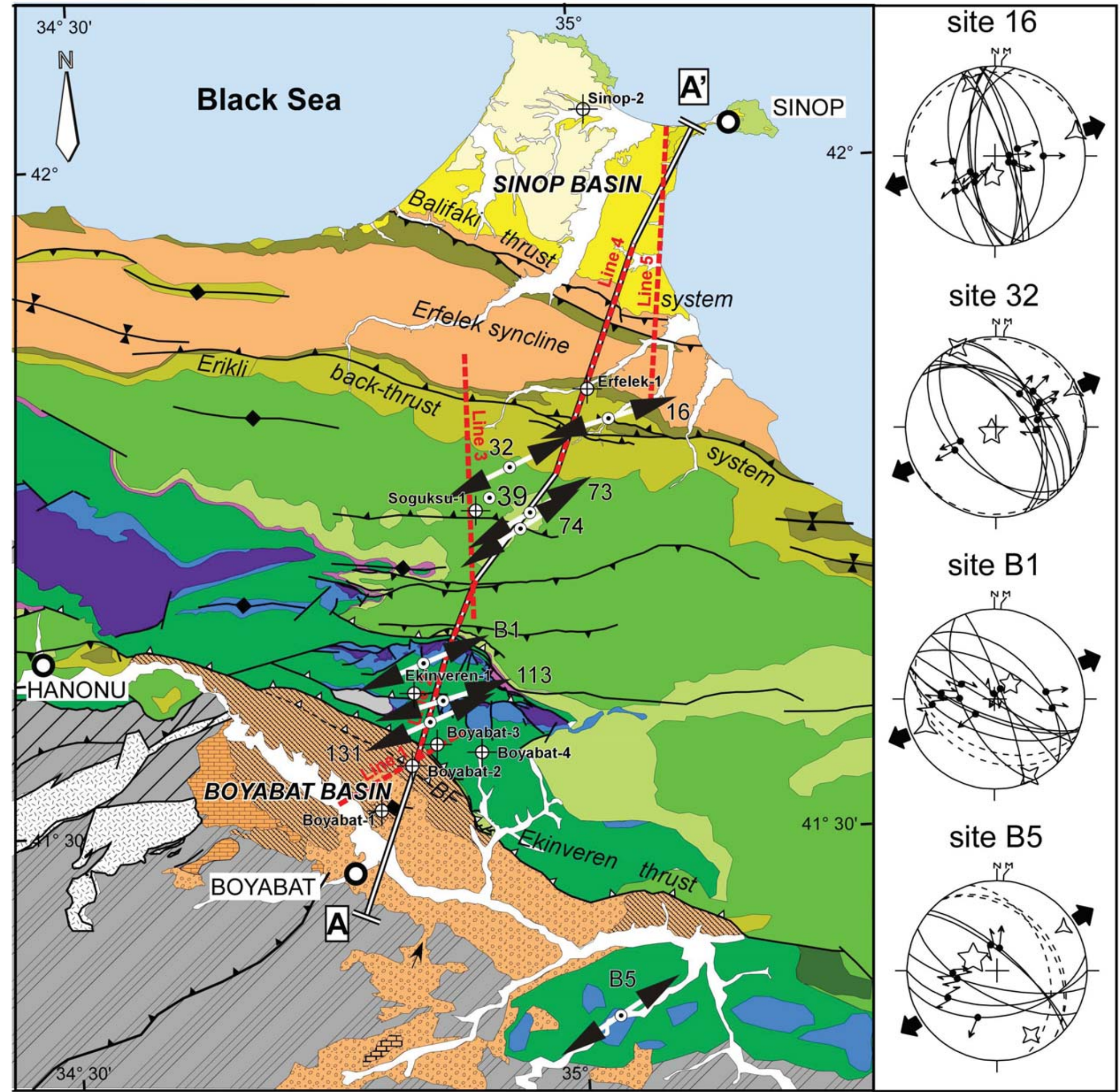




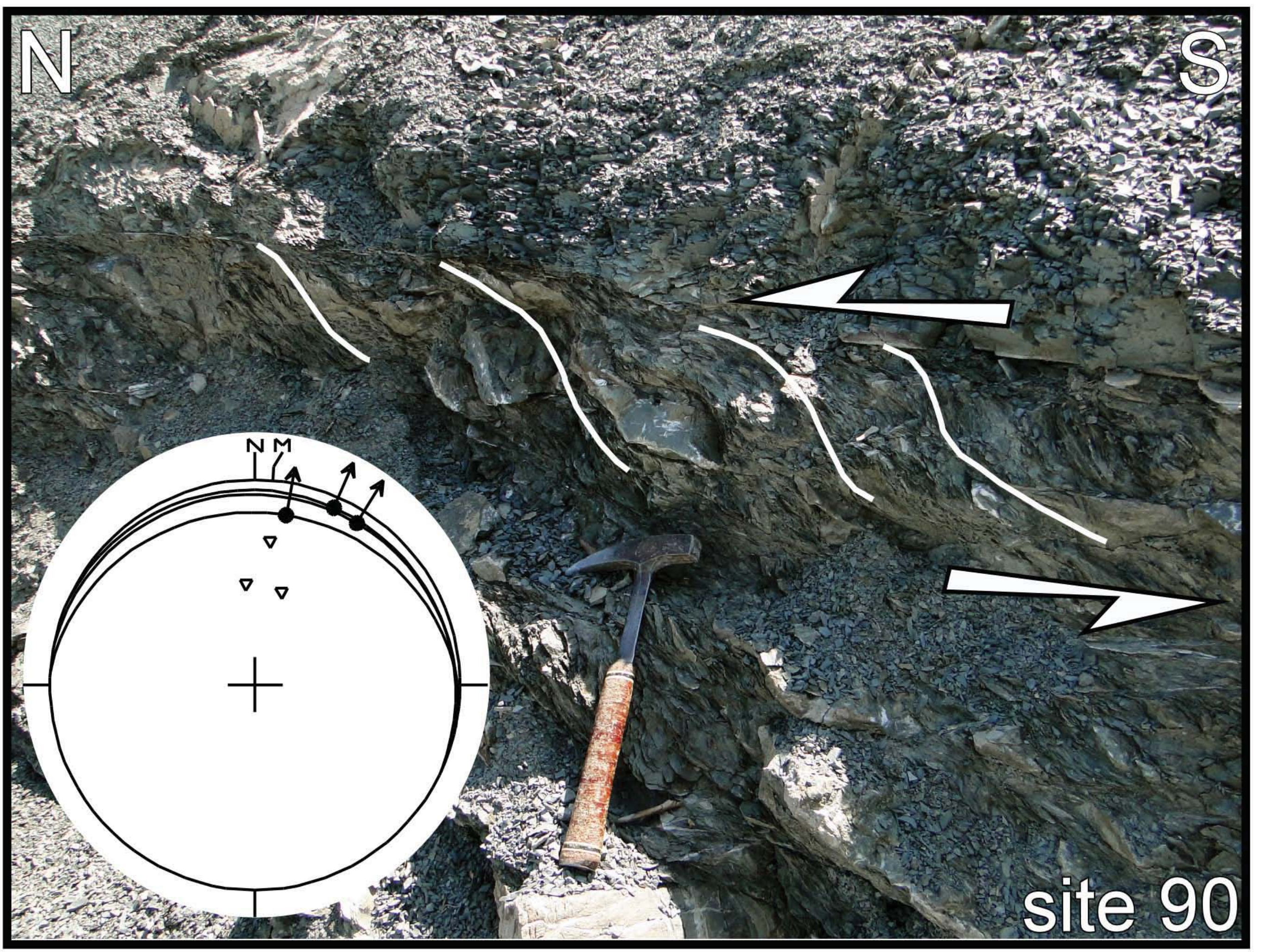




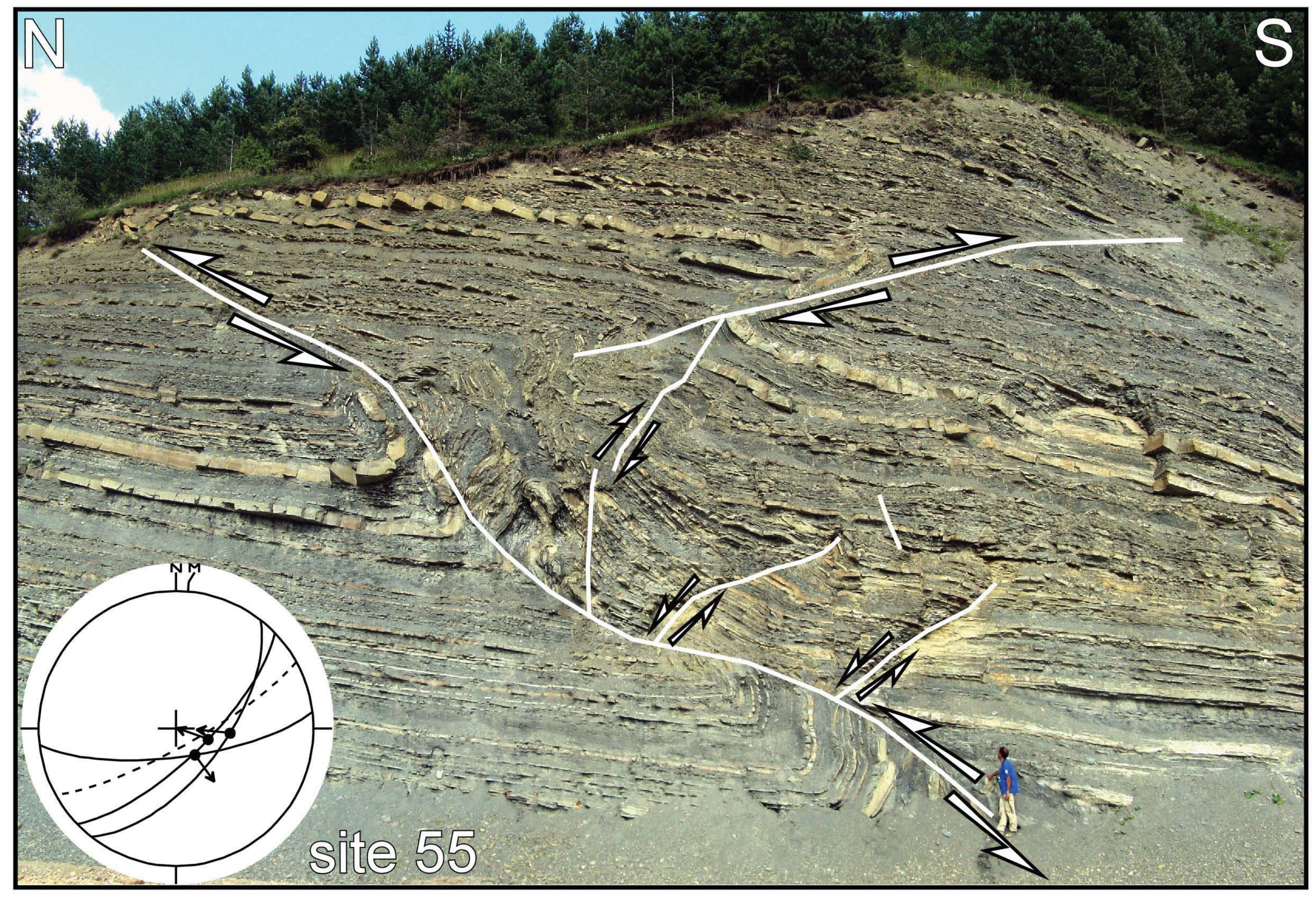



















sample name Longitude $(\mathrm{m}) \quad$ Latitude $(\mathrm{m})$ Formation

\begin{tabular}{|clll} 
SI-11 & 675317 & 4635927 & Kusuri \\
SI-23 & 667751 & 4629173 & Akveren \\
SI-24 & 667594 & 4629747 & Atbaşi \\
SI-25 & 666781 & 4629020 & Akveren \\
SI-31 & 661279 & 4626756 & Gürsökü \\
SI-40 & 658686 & 4623186 & Gürsökü \\
SI-49 & 656421 & 4616038 & Gürsökü \\
SI-61 & 654996 & 4613177 & Gürsökü \\
SI-70 & 664082 & 4624960 & Gürsökü \\
SI-72 & 663036 & 4623537 & Yemişliçay \\
SI-80 & 658780 & 4617079 & Gürsökü \\
SI-84 & 659367 & 4615509 & Gürsökü \\
SI-88 & 660083 & 4614342 & Gürsökü \\
SI-96-A & 657826 & 4611551 & Çağlayan \\
SI-96-C & 657805 & 4611481 & Kapanbogazi \\
SI-96-D & 657826 & 4611551 & Yemişliçay \\
SI-109 & 656235 & 4607696 & Çağlayan \\
SI-111 & 655472 & 4607837 & Çağlayan \\
SI-114 & 655287 & 4607045 & Çağlayan \\
SI-123-1 & 654105 & 4612072 & Yemişliçay \\
SI-123-2 & 654053 & 4612024 & Çağlayan \\
SI-131 & 654256 & 4605069 & Çağlayan \\
SI-135 & 652370 & 4603658 & Kusuri \\
SI-137 & 651738 & 4603235 & Kusuri \\
SI-147 & 653221 & 4603240 & Kusuri \\
SI-153 & 652428 & 4600188 & Kusuri \\
$04-22$ & 669099 & 4630111 & Akveren \\
04-24 & 675286 & 4587100 & Kusuri \\
04-25 & 658851 & 4594733 & Kusuri \\
04-26 & 646635 & 4597624 & Kusuri \\
$04-80$ & 669955 & 4587553 & Kusuri \\
$04-82$ & 644051 & 4598104 & Kusuri \\
\hline & & & \\
\hline
\end{tabular}


Age

Lower Eocene NP12

Lower Paleocene NP3

Upper Paleocene NP9

Middle Maastrichtian

Upper Campanian

Lower Campanian

Lower Campanian

Upper Campanian

Upper Campanian

Lower Campanian

Lower Campanian

Upper Campanian - Lower Maastichtian

Lower Campanian

Early Cretaceous

Santonian - Lower Campanian

Lower Campanian

Early Cretaceous, Aptian ?

Upper Aptian

Upper Aptian

Lower Campanian

Early Cretaceous, Aptian ?

Upper Aptian

Lower Eocene

Lower Eocene NP12 ?

Lower Eocene NP13

Lower Eocene NP13

Upper Paleocene

Lower Eocene NP13

Middle Eocene NP14

Lower Eocene NP13

Lower Eocene NP12

Middle Eocene NP14 
Coccolithus pelagicus, Sphenolithus moriformis, S. radians, Cycloccolithus formosus, Chiasmolithus solitus, $\mathrm{C}$ Coccolithus pelagicus, Ericsonia subpertusa, Cruciplacolithus tenuis, Chiasmolithus danicus

Discoaster multiradiatus, Toweius eminens, Coccolithus pelagocus, Fasciculiyhus tympaniformis, Ericsonia sı Arkhangelskiella cymbiformis, Eiffellithus turiseiffeli, Micula staurophora, Lithraphidites quadratum, Predisc Quadrum trifidum, Watznaueria barnesae, Reinhardtites anthophorus, Micula staurophora, Broinsonia parc Broinsonia parca, Eiffellithus eximius,E. turriseiffeli, Micula staurophora, Prediscosphaera cretacea, Watzna। Broinsonia parca, Eiffellithus eximius,E. turriseiffeli, Micula staurophora, Prediscosphaera cretacea, Watzna। Watznaueria barnesae, Micula staurophora, Prediscospaera cretacea, Eiffellithus eximius, Quadrum gothicu Watznaueria barnesae, Micula staurophora, Prediscospaera cretacea, Eiffellithus eximius, Quadrum gothicu Watznaueria barnesae, Prediscoshaera cretacea, Micula staurophora, Reinhardttes anthophorus, Eiffellithu: Watznaueria barnesae, Prediscoshaera cretacea, Micula staurophora, Reinhardttes anthophorus, Eiffellithu: Watznaueria barnesae, Micula staurophora, Lucianorhabdus cayeuxi, Tetralithus aculeus, Quadrum gothicu। Eifellithus turrseiffeli, E. eximius, Broinsonia parca, Lithraphidites cayeuxi, Watznaueria barnesae Watznaueria barnesae, Ellipsolithus communis

Watznaueria barnesae, Micula staurophora, Ellipsolithus communis, Eifellithus eximius, Marthasterites furc Micula staurophora, Watznauera barnesae, Ellipsolithus communis, Eiffellithus eximius, Broinsnia parca, Mi Watznaueria barnesae, Ellipsopshaera communis, Parhabdoithus asper

Watznaueria barnesae, Ellipsosphera communis, Eprolithus floralis, Parhabdolithus embergeri, Chiasozygus Watznaueria barnesae, Ellipsosphera communis, Eprolithus floralis, Parhabdolithus embergeri, Chiasozygus Arkhangelskiella cymbiformis, Eiffelithus eximius, Broinsonia parca, Micula staurophra, Lithraphidites cayex Watznaueria barnesae, Ellipsosphaera communis

Watznaueria barnesae Parhabdolitus infinitus, Chiastozygus litterarius, Eprolithus floralis Coccolithus pelagicus, Helicosphaera lophota, Cyclococcolithus gammation

Coccolithus pelagicus, Sphenolithus moriformis, Toweius sp., Discoaster diastypus, D. lodoensis, Cyclococcol Cyclococcolithus formosus, Discoaster lodoensis, D. barbadiensis, Cyclococcolithus gammation, Sphenolithu Coccolithus pelagicus, Zyghrablithus bijugatua, Cyclococcoitus formosus, Sphenolithus radians, Discoaster Id Fasciclithus tympaniformis, Ericsnia subpertusa, Cruciplacolithus tenuis, Coccolithus pelagicus Discoaster lodoensis, D. barbadiensis, Cyclococcolithus gammation, Chiasmolithus solitus, Cyclococcolithus 1 Discoaster sublodoensis, D. barbadiensis, D. nonaradiatus, Cyclococcolithus formosus, Chiasolithus solitus, ( Discoaster lodoensis, D. barbadiensis, Cyclococcolithus gammation, Chiasmolithus solitus, Cyclococcolithus 1 Mathasterites tribrachiatus, Cyclococcolithus formosus, Sphenolithus radians, Discoaster lodoensis, D. binor Discoaster sublodoensis, D. barbadiensis, D. nonaradiatus, Cyclococcolithus formosus, Chiasolithus solitus, ( 
Zyclococcolithus gammation, Marthasterites tribrachiatus, Discoaster lodoensi, D.binodosus, Helicos

ubpertusa, Discoaster diastypus, Sphenolithus annorphobus, Chiasmolithus bidens

zosphaera cretacea, Watznaueria barnesae

a, Eiffellithus eximius, E.turriseiffeli, Prediscosphaera cretacea

ueria barnesae, Tetralithus obscurus, T. aculeus, Ellipsophaera communis

ueria barnesae, Tetralithus obscurus, T. aculeus, Ellipsophaera communis

$\mathrm{m}$, Broinsonia parca, Tetralithus aculeus, Lucianorhabdus cayeuxi

$\mathrm{m}$, Broinsonia parca, Tetralithus aculeus, Lucianorhabdus cayeuxi

5 eximius, E. turriseiffeli, Broinsonia parca

5 eximius, E. turriseiffeli, Broinsonia parca

m

atus

arthasterites furcatus

litterarius, Rucinolithus irregularis

litterarius, Rucinolithus irregularis

i, Watznaueria barnesae

lithus gammation, Cyclococcolithus formosus, Helicosphera ophota $s$ radians, $\mathbf{S}$. moriformis, Helicosphaera lophota, Zygrhalithus bijugatus Ioensis, Cyclococcolithus gammation, Chiasmolithus solitus

formosus, Coccolithus pelagicus

Zoccolithus pelagicus, Reticulofenestra cf. umbilica

formosus, Coccolithus pelagicus

dosus, D. barbadiensis, Coccolithus pelagicus, Cyclococcolithus gammation

zoccolithus pelagicus, Reticulofenestra cf. umbilica 
iphaera lophota 


\section{Site name}

SINOP1

SINOP2

SINOP3

SINOP5

BOYA1

BOYA1

BOYA2

BOYA3

BOYA5

BOYA5

BOYA5

BOYA7

BOYA7

BOYA9

BOYA19

BOYA19

16

32

39

73

74

113

131

\section{northing UTM 36 easting UTM 36}

4644575
4656141
4624518
4619019
4609944
4609944
4587704
4592556
4580826
4580826
4580826
4591213
4591213
4604709
4586548
4586548
4630288
4626206
4623576
4622527
4621256
4606841
4605069

\section{age of rocks}

635451

679902

685027

636999

653700

653700

664021

670455

669993

669993

669993

656419

656419

637504

666630

666630

668998

660753

659058

662487

661694

655302

654256
Lower-Middle Eocene Upper Senonian

Late Cretaceous-Eocene Jurassic-Cretaceous

Berriasian-Valanginian

Berriasian-Valanginian

$$
\text { Eocene }
$$

Early cretaceous

Late Jurassic

Late Jurassic

Late Jurassic

Eocene

Eocene

Lower-Middle Eocene

Eocene

Eocene

Upper Paleocene NP9

Upper Campanian

Lower Campanian

Coniacian-Lower Campanian

Coniacian-Lower Campanian Aptian

Aptian $\begin{array}{lllllll}\text { stress number } & \sigma 1 & \sigma 2 & \sigma 3 & \Phi & \text { ANG RUP }\end{array}$

regime of faults tr. pl. tr. pl. tr. pl.

$\begin{array}{ccccccccccc}\text { C } & 10 & 201 & 7 & 292 & 5 & 59 & 82 & 0,42 & 8 & 25 \\ \text { S } & 5 & 8 & 11 & 185 & 79 & 278 & 1 & 0,60 & 3 & 7 \\ \text { C } & 12 & 192 & 15 & 282 & 3 & 22 & 75 & 0,08 & 15 & 39 \\ \text { S } & 8 & 239 & 10 & 48 & 80 & 149 & 2 & 0,96 & 15 & 32 \\ \text { S } & 9 & 293 & 4 & 71 & 84 & 203 & 4 & 0,36 & 12 & 40 \\ \text { E } & 9 & 46 & 70 & 156 & 7 & 248 & 19 & 0,63 & 18 & 41 \\ \text { C } & 21 & 206 & 4 & 296 & 5 & 77 & 83 & 0,10 & 9 & 30 \\ \text { S } & 14 & 8 & 6 & 130 & 79 & 277 & 9 & 0,45 & 8 & 28 \\ \text { S } & 10 & 148 & 1 & 47 & 83 & 238 & 7 & 0,40 & 15 & 38 \\ \text { C } & 7 & 31 & 8 & 122 & 8 & 257 & 79 & 0,14 & 10 & 40 \\ \text { E } & 6 & 297 & 66 & 152 & 20 & 57 & 13 & 0,20 & 7 & 35 \\ \text { C } & 11 & 211 & 2 & 301 & 4 & 98 & 85 & 0,35 & 16 & 44 \\ \mathrm{C} & 9 & 335 & 11 & 244 & 7 & 121 & 76 & 0,60 & 7 & 18 \\ \mathrm{~S} & 16 & 211 & 18 & 333 & 58 & 112 & 26 & 0,30 & 17 & 47 \\ \mathrm{C} & 13 & 230 & 14 & 332 & 39 & 125 & 48 & 0,22 & 8 & 32 \\ \mathrm{~S} & 8 & 163 & 19 & 46 & 53 & 265 & 30 & 0,37 & 16 & 50 \\ \mathrm{E} & 10 & 189 & 73 & 342 & 16 & 74 & 8 & 0,50 & 9 & 33 \\ \mathrm{E} & 9 & 168 & 65 & 350 & 25 & 259 & 1 & 0,22 & 6 & 21 \\ \mathrm{E} & 2 & & & & & & & & & \\ \mathrm{E} & 13 & 238 & 73 & 331 & 1 & 61 & 17 & 0,28 & 13 & 49 \\ \mathrm{E} & 7 & 331 & 60 & 148 & 30 & 239 & 2 & 0,48 & 6 & 43 \\ \mathrm{E} & 9 & 170 & 27 & 349 & 63 & 80 & 1 & 0,30 & 10 & 23 \\ \mathrm{E} & 10 & 358 & 30 & 134 & 51 & 254 & 22 & 0,64 & 7 & 28\end{array}$

